\title{
UPAYA PENANGGULANGAN TINDAK PIDANA DI BIDANG PERBANKAN MELALUI PENDEKATAN KEBIJAKAN REGULASI
}

\author{
Oleh : \\ M. Zen Abdullah *
}

\begin{abstract}
ABSTRAK
Penellitian ini bertujuan untuk mengetahui dan mendiskripsikan kebijakan regulasi peraturan perundang- undangan dalam penanggulangan tindak pidana di bidang perbankan. Serta menjelaskan beberapa faktor yang merupakan penghambat dalam penanggulangan tindak pidana di bidang perbankan sehingga memberikan manfaat berupa masukan dan rujukan dengan upaya penanggulangan tindak pidana di bidang perbankan melalui pendekatan kebijakan regulasi dan penerapan pidana. Penelitian menggunakan metode penelitian hukum normatif yang dipadukan dengan penelitian hukum empiris sebagai bahan penunjang/pelengkap. Kebijakan regulasi dalam upaya penanggulangan tindak pidana di bidang per-bankan diatur di dalam dan di luar Undang- undang Perbankan, yang di dalam Undang-undang Perbankan telah dirumuskan dan dituangkan ketentuannya di dalam pasal 46 hingga pasal 50A Undang- undang Perbankan Nomor 7 Tahun 1992 yang diperbaharui dengan Undang- undang Nomor 10 Tahun 1998, se-dangkan di luar ketentuan Undang- undang Perbankan, yang dituangkan dan diatur di dalam Kitab Undang- undang Hukum Pidana (KUHP), Undang- undang Pemberantasan Tindak Pidana Korupsi, Undang- undang Penanaman Modal, Undang- undang Pencegahan dan Pemberantasan Tindak Pidana Pencucian Uang, Undang- undang Informasi dan Transaksi Elektronik dan Undang- undang Transper Dana. Beberapa faktor yang merupakan penghambat dalam penanggulangan tindak pidana di bidang perbankan, dapat dilihat dari baik aspek substansi/materi yang termuat di dalam Undang- undang Perbankan, di mana norma/ kaidah hukumnya masih kabur, kurang jelas dan kurang tegas dan belum sepenuhnya mampu menanggulangi berbagai jenis dan modus tindak pidana di bidang perbankan yang terjadi dan berkembang saat ini. Dilihat dari aspek struktur/ kelembagaan aparat penegak hukum, masih terjadi tumpang tindih (overlaping) dan kurang harmonisnya antar aparat penegak hukum dalam hal kewenangan melakukan penyelidikan dan penyidikan tindak pidana di bidang perbankan yang diatur dalam Undang- undang. Keterbatasan kualitas (keahlian, ketrampilan, penga-laman dan pengetahuan) yang belum memadai penguasaan dan penggunaan tehnologi informasi, internet banking, data- data digital/ elektronik, komputeri-sasi dan lainnya, keterbatasan sarana dan prasarana tehnologi informasi maupun dari aspek kultur/budaya aparat penegak hukum yang berprilaku yang berbeda dengan hal yang sebenarnya yang terkandung dalam aturan yang diterapkan, seringkali bermain dengan peraturan dan prosedur.
\end{abstract}

Kata Kunci : Tindak Pidana Perbankan, Kebijakan Regulasi

\section{A. Latar Belakang}

Keberadaan lembaga keuangan perbankan bertujuan untuk menunjang pelaksanaan pembangunan nasional dalam rangka meningkatkan pemerataan, pertumbuhan ekonomi

\footnotetext{
* Pengajar Program Magister Ilmu Hukum Unbari.
} 
dan stabilitas nasional kearah peningkatan kesejahtraan rakyat banyak. Ketentuan ini menunjukkan bahwa lembaga perbankan mempunyai peran penting bukan hanya dalam menggerakkan roda perekonomian nasional, tetapi juga diarahkan agar mampu menunjang pelaksanaan pembangunan nasional. ${ }^{1}$

Pembangunan nasional tidak akan dapat dicapai dengan baik tanpa didukung dengan pembangunan ekonomi, pembangunan ekonomi hanya dapat berjalan dengan lancar apabila ditunjang dengan keberadaan industri perbankan. Keberadaan industri perbankan dalam kehidupan masyara-kat dewasa ini, mempunyai peran yang cukup penting, karena industri perbankan merupakan wadah menyimpan dana dan sebagai sarana dalam melakukan berbagai transaksi keuangan, melalui pengumpulan dana tersebut, perbankan dapat menyalurkannya kembali dana yang sudah terkumpul kepada masyarakat kepada pihak yang membutuhkan, untuk menopang tujuan pembangunan nasional.

Di dunia modern saat ini, peran perbankan sangat besar sekali dalam mendorong dan menopang pertumbuhan perekonomian suatu negara. Hampir semua sektor usaha, yang meliputi sektor indutri besar, me-nengah, kecil, sektor perdagangan, pertanian, perkebunan, pertambangan, jasa dan perumahan sangat membutuhkan bank sebagai mitra dalam melakukan transaksi keuangannya. Boleh dikatakan industri perbankan memiliki fungsi yang cukup penting bagi dunia usaha, pelaku bisnis dan masyarakat dalam menunjang kelancaran transaksi keuangan yang dibutuhkannya dan sekaligus untuk mendukung kelancaran usahanya.

Lembaga perbankan sebagai lembaga financial intermediasi (peran-tara keuangan) dalam peranannya tersebut, terdapat hubungan antara bank dengan nasabahnya didasarkan pada dua unsur yang saling terkait, yaitu unsur hukum dan kepercayaan. Suatu bank hanya dapat melakukan kegiatan dan mengembangkan banknya, apabila masyarakat percaya untuk menempatkan uangnya dalam produk- produk perbankan yang ada pada perbankan tersebut. Berdasarkan kepercayaan masyarakat dimaksud, perbankan dapat memobilisasi dana dari masyarakat untuk ditempatkan di perbankan dan menyalurkannya kembali dalam bentuk pemberian kredit serta memberikan jasa- jasa perbankan lainnya.

Kepercayaan yang diberikan masyarakat (nasabah) penyimpan dana, agar dapat dijalankan secara maksimal, lembaga perbankan dituntut dapat menerapkan prinsif kehatihatian. Artinya, dalam mengelola bisnis perbankan manajemen bank harus bertindak secara cermat dan teliti dalam memasarkan produk serta layanan jasanya, harus tetap selalu kon-

\footnotetext{
${ }^{1}$ Hermansyah, 2009, Hukum Perbankan Nasional Indonesia, Kencana : Jakarta, Halaman 41.
} 
sisten dalam melaksanakan peraturan perundang- undangan di bidang perbankan berdasarkan profesionalisme dan itikad baik. ${ }^{2}$

Penerapan prinsif kehati-hatian dilakukan oleh industri perbankan dengan tujuan untuk menjaga tingkat keamanan, tingkat kesehatan bank agar dapat dijaga dan terkendali dengan baik serta kestabilan sistem perbankan itu sendiri. Dengan menerapkan prinsif kehati- hatian agar bank tetap berada dalam keadaan sehat, stabil dan likuid (kemampuan memenuhi kewajibannya) yang dengan demikian diharapkan dapat me-numbuhkan kepercayaan masyarakat terhadap industri perbankan, dengan tumbuhnya kepercayaan masyarakat terhadap industri perbankan menga-kibatkan bank dapat berperan dengan aktif dalam menjalankan fungsi intermediasi (perantara antara penyimpan dengan peminjam uang).

Kontribusi yang besar dari industri perbankan sebagai lembaga perantara keuangan adalah dalam rangka meningkatkan pertumbuhan perekonomian nasional. Hal ini dapat dilihat dari meningkatnya peran intermediasi (perantara antara penyimpan dengan peminjam uang) dengan baik, dilihat dari sisi peningkatan asset, kredit dan dari sisi dana pihak ketiga, masing- masing tumbuh dengan angka sebesar 13,34\%, 11,58\% dan 12,29\%.

Peningkatan kinerja industri perbankan tersebut dilihat dari sisi internal yang disertai dengan perbaikan kualitas pertumbuhan yang tercermin dari tingginya peran investasi swasta, penurunan tingkat pengangguran dan kemiskinan serta pemerataan pertumbuhan ekonomi antar daerah yang semakin membaik. Sedangkan dari sisi eksternal, neraca pembayaran Indonesia mengalami surplus (kelebihan) dengan ca-dangan devisa yang meningkat dan nilai tukar rupiah yang mengalami apresiasi.

Perkembangan industri perbankan dengan memasuki era globalisasi dan liberalisasi pasar keuangan saat ini, telah mengakibatkan mening-katnya persaingan di antara bankbank terutama dalam penghimpunan dana. Untuk itu, manajemen bank dituntut mempunyai ketrampilan mengelola kekayaan, utang dan modal bank yang tercermin dalam neraca bank dengan baik. Suatu hal yang lebih mendasar dari keahlian dan ketrampilan tersebut adalah adanya itikad baik. Artinya, pengurus bank seharusnya adalah pihak yang selalu menjunjung tinggi kode etik perbankan dan mematuhi segala peraturan perundang- undangan di bidang perbankan yang berlaku.

Industri perbankan sebagai lembaga keuangan seringkali dihadapi dengan berbagai persoalan yang mendasar. Bukan hanya menghadapi persoalan internal yang menyangkut

\footnotetext{
${ }^{2}$ Hermansyah, Op, Cit, Halaman 135.
} 
meminimalkan pengendalian berba-gai manajemen risiko yang mungkin dan akan terjadi di lingkungan perbankan, terkait dengan 'risiko kredit, risiko pasar, risiko operasional, risiko likuiditas, risiko hukum, risiko reputasi dan risiko kepatuhan'. Namun demikian, lebih dari itu industri perbankan dihadapi pula dengan beraneka ragam beban tugas dalam menjalankan kegiatan usaha perban-kan. Beban tugas dimaksud, meliputi mulai dari kegiatan memasarkan produk penghimpunan dana dalam bentuk simpanan rekening giro, tabungan, deposito berjangka, perdagangan surat berharga, produk kredit dalam bentuk penyaluran dana kredit konsumtif dan juga kredit produk-tif/komersial, produk jasa layanan di luar penghimpunan dana dan penya-luran kredit dalam rangka menghimpun pendapatan non bunga (fee based income), yaitu layanan pembayaran rekening titipan (payment point) listrik, air bersih, layanan transper (pengiriman uang) dan layanan pertukaran/jual beli valuta asing (money changer) hingga layanan mengguna-kan perbankan elektronik (electronic banking) yang mencakup ATM banking, kartu debit, kartu kredit dan lainnya.

Jasa-jasa perbankan lainnya yang meliputi penyewaan kotak pe-nyimpan harta atau surat- surat berharga (safe deposit box), inkaso (layanan bank untuk penagihan pembayaran atas surat/dokumen berharga kepada pihak ketiga di tempat lain), kustodian (pihak yang memberikan jasa penitipan efek dan harta lain yang berkaitan dengan efek serta jasa lain, termasuk menerima deviden, bunga dan lainnya, menyelesaikan transaksi efek dan mewakili pemegang rekening yang menjadi nasa-bahnya), referensi bank (keterangan dalam bentuk surat yang dikeluarkan oleh bank yang diberikan kepada seseorang atau badan usaha yang menjadi nasabahnya berisikan identitas seseorang atau badan usaha) dan lainnya.

Kompleks dan beragam serta variatifnya layanan produk dan layanan jasa- jasa perbankan yang ditawarkan dan dipasarkan industri perbankan pada masyarakat, dengan jumlah dana yang dikelola aktivitas bisnis cukup besar, melibatkan banyaknya nasabah dari berbagai jenis produk, termasuk aktivitas penyaluran kredit yang bervariatif, dengan layanan- layanan jasa beragam, penggunaan tehnologi (electronic ban-king) yang jangkauannya cukup luas dan memudahkan dalam transaksi antar nasabah, lemahnya sistem pengawasan internal (internal control) yang dilakukan bank yang bersangkutan maupun pengawasan otoritas yang berwenang, adanya moral hazard (prilaku jahat), mengakibatkan industri perbankan rentan akan terjadi penyimpangan- penyimpangan/ penyalahgunaan kewenangan yang mengarah pada perbuatan melanggar hukum, baik 
pelanggaran yang berakibat dijerat dan/ atau diterapkan sanksi perdata, sanksi administratif maupun yang berupa sanksi pidana yang berkaitan dengan menjalankan bisnis bank.

Sanksi pidana diatur dalam ketentuan pasal 46 hingga pasal 50A Undang- undang Perbankan Nomor 7 Tahun 1992 yang diperbaharui dengan Undang- undang Nomor 10 Tahun 1998, yang di dalamnya terdapat beberapa jenis tindak pidana perbankan, yaitu tindak pidana yang berkaitan dengan perizinan, tindak pidana yang berkaitan dengan rahasia bank, tindak pidana yang berkaitan dengan pengawasan dan pembinaan bank, tindak pidana yang berkaitan dengan usaha bank dan tindak pidana yang berkaitan dengan pihak teralifiasi.

Selain tindak pidana perbankan yang terdapat dan diatur dalam Undang- undang Perbankan Nomor 7 Tahun 1992 yang diperbaharui dengan Undang- undang Nomor 10 Tahun 1998, terdapat juga tindak pidana yang berkaitan dengan kegiatan perbankan lainnya, seperti tindak pidana pemalsuan warkat dan/ atau dokumen bank dalam pemberian kredit, tindak pidana penipuan, penggelapan dana nasabah dan lainnya yang diatur dalam pasal 263, pasal 264, pasal 372 dan pasal 374 Kitab Undang- undang Hukum Pidana (KUHP) Nomor 1 Tahun 1946. Penyalahgunaan wewenang/jabatan sebagai direksi, pejabat dan pegawai bank dengan menerima imbalan, hadiah dan lainnya yang dijerat dan diatur dalam Undang- undang Pemberantasan Tindak Pidana Korupsi Nomor 31 Tahun 1999 yang diperbaharui dengan Undang- undang Nomor 20 Tahun 2001, tindak pidana yang berkaitan bank sebagai kustodian dan tindakan bank sebagai wali amanat, dimana bank tidak memiliki izin dan tidak terdaftar di pasar modal yang melanggar UndangUndang Pasar Modal Nomor 8 Tahun 1995, tindak pidana menyimpan uang hasil kejahatan (kejahatan korupsi, narkotika, perdagangan senjata gelap, perampo-kan) yang dananya ditempatkan di perbankan yang diatur dengan Undang- undang Pencegahan dan Pemberantasan Tindak Pidana Pencu-cian uang Nomor 25 Tahun 2003 yang diperbaharui dengan Undang- undang Nomor 8 Tahun 2010 dan lainnya.

Tindak pidana di bidang perbankan, walaupun sudah ada kebijakan regulasi yang mengatur dan memberikan ancaman sanksi pidana, baik yang termuat di dalam dan di luar Undang- undang Perbankan Nomor 7 Tahun 1992 yang diperbaharui dengan Undangundang Nomor 10 Tahun 1998. Begitu juga dalam penegakan hukum dan penerapan pidana sudah banyak pelaku tindak pidana di bidang perbankan yang dijerat dan divonis pidana. Secara kasat mata dalam praktiknya modus operandi tindak pida-na di bidang perbankan kian hari terus- menerus meningkat, baik dari sisi kualitas maupun kuantitasnya. 
Bukan hanya dilakukan oleh orang yang berada di luar bank. Namun demikian juga dapat dilakukan oleh orang di dalam bank itu sendiri dan dapat pula terjadi kerja sama antara orang dalam maupun orang di luar bank, yang menjadikan bank sebagai sararan/ objek kejahatan (crime against the bank), bank sebagai sarana untuk melakukan kejahatan (crime through the bank) dan bank sebagai pelaku kejahatan (crime by the bank).

Permasalahannya, apakah kebijakan regulasi peraturan perundang- undangan yang termuat di dalam pasal 46 hingga pasal 50 Undang- undang Perbankan Nomor 7 Tahun 1992 yang diperbaharui dengan Undang- undang Nomor 10 Tahun 1998 dalam implementasi dan/atau penerapan pidananya sudah cukup memadai dalam menanggulangi tindak pidana di bidang perbankan. Hal inilah yang menjadikan penulis tertarik untuk melakukan penelitian dengan judul "Upaya Penanggulangan Tindak Pidana di Bidang Perbankan Melalui Pendekatan Kebijakan Regulasi ”.

\section{B. Perumusan Masalah}

Berdasarkan latar belakang masalah yang dipaparkan di atas, maka perumusan masalah yang dikemukakan adalah sebagai berikut :

1. Bagaimanakah kebijakan regulasi peraturan perundang- undangan dalam penanggulangan tindak pidana di bidang perbankan?

2. Faktor- faktor apakah yang merupakan penghambat dalam penanggu-langan tindak pidana di bidang perbankan?

\section{Kebijakan Regulasi Peraturan Perundang- undangan Dalam Penanggu-langan Tindak Pidana di Bidang Perbankan}

Kebijakan regulasi diartikan sebagai suatu usaha untuk menyusun, merumuskan dan menetapkan suatu perundang- undangan pidana yang baik, yang dapat dijadikan sebagai pedoman tidak hanya kepada pembuat Undang- undang, tetapi juga kepada pengadilan yang menerapkan Undang- undang dan juga kepada penyelenggara nega-ra atau pelaksana putusan pengadilan. ${ }^{3}$ Peraturan perundang- undangan yang baik, diharapkan dapat menanggulangi kejahatan dan khususnya tindak pidana di bidang perbankan yang semakin hari semakin berkembang terus baik kualitas maupun kuantitasnya.

Dalam mencegah dan menanggulangi tindak pidana di bidang perbankan, di samping diperlukan peningkatan fungsi kontrol bank baik yang dilakukan internal bank maupun

\footnotetext{
${ }^{3}$ Barda Nawawi Arief, Op, Cit, Halaman 23.
} 
dari Bank Indonesia (sekarang Otoritas Jasa Keuangan) harus diper-ketat dan diperkuat dengan menentukan standar operasional yang baku, menjaga ketaatan tata cara dan proses dalam kegiatan perbankan, pengawasan terhadap mana-jemen dan menjaga secara ketat prinsif kehati- hatian dan standar moral dari pihak bank. ${ }^{4}$ Tidak kalah pentingnya adanya regulasi aturan perundang- undangan seba-gai dasar hukum bagi aparat penegak hukum dalam penanggulangan tindak pidana di bidang perbankan.

Adapun peraturan perundang- undangan yang merupakan kebijakan regulasi dalam mengatur, merumuskan, menetapkan kreteria tindak pidana di bidang per-bankan tersebar di berbagai peraturan perundang- undangan, baik yang tertuang di dalam Undang- Undang Perbankan Nomor 7 Tahun 1992 yang diperbaharui dengan Undang- undang Nomor 10 tahun 1998 maupun yang berada di luar Undang- undang Perbankan Nomor 10 Tahun 1998.

\section{Kebijakan Regulasi Yang Termuat Di dalam Undang- Undang Perbankan Nomor 10 Tahun 1998}

Undang- Undang Nomor 7 Tahun 1992 Tentang Perbankan sebagaimana telah diubah dengan Undang- Undang Nomor 10 Tahun 1998, memiliki peran yang sangat penting dalam mewujudkan suatu sistem perbankan nasional yang kuat, sehat dan tangguh. Di dalam Undang- undang Perbankan yang terdiri dari 10 Bab dan 60 pasal, diatur mulai dari azas, fungsi dan tujuan perbankan, jenis dan usaha bank, prihal perizinan, bentuk hukum dan kepemilikan, pembinaan dan pengawasan bank serta termasuk ketentuan pidana dan sanksi administratif.

Ketentuan pidana dan sanksi administratif yang dicantumkan dalam Bab VIII mulai pasal 46 hingga pasal 53 Undang- Undang Perbankan Nomor 10 Tahun 1998, ditujukan untuk mencegah dan menanggulangi dalam penyelenggaraan kegiatan industri di bidang perbankan dari praktik- praktik bisnis kotor, tercela dan menim-bulkan kerugian bagi masyarakat yang terindikasi melawan hukum dan merupakan perbuatan pidana, maka terhadap perbuatan/praktik- praktik kotor, tercela dan meru-gikan kepentingan masyarakat dan terindikasi melawan hukum yang merupakan perbuatan pidana di dalam menyelenggarakan industri perbankan terhadapnya dike-nakan sanksi pidana. Sanksi pidana di dalam Undang- Undang Perbankan Nomor 10 Tahun 1998, dimuat dan diatur

${ }^{4}$ Yenti Garnasih, Mei 2015, Materi Seminar 'Optimalisasi Penelusuran Hasil Tindak Pidana Perbankan' yang diselenggarakan LPS dan Jurnalis Indonesia, Jakarta, Halaman 12. 
mulai dari pasal 46, 47, 47A 48, 49, 50 dan pasal 50A, yang menggambarkan berbagai jenis tindak pidana perbankan seperti tertera dalam tabel berikut ini ;

Tabel 1

Jenis- jenis Tindak Pidana Perbankan Berdasarkan
Undang- undang Perbankan Nomor 10 Tahun 1998

\begin{tabular}{|c|l|l|}
\hline No & \multicolumn{1}{|c|}{ Jenis- jenis Tindak Pidana } & \multicolumn{1}{|c|}{ Pasal } \\
\hline 1 & Tindak pidana yang berkaitan dengan perizinan & Pasal 46 \\
\hline 2 & $\begin{array}{l}\text { Tindak pidana yang berkaitan dengan rahasia } \\
\text { bank }\end{array}$ & Pasal 47 dan pasal 47A \\
\hline 3 & $\begin{array}{l}\text { Tindak pidana yang berkaitan dengan penga- } \\
\text { wasan dan pembinaan bank }\end{array}$ & Pasal 48 \\
\hline 4 & $\begin{array}{l}\text { Tindak pidana yang berkaitan dengan usaha } \\
\text { bank }\end{array}$ & Pasal 49 \\
\hline 5 & $\begin{array}{l}\text { Tindak pidana yang berkaitan dengan pihak } \\
\text { teralifiasi }\end{array}$ & Pasal 50 dan pasal 50A \\
\hline
\end{tabular}

Sumber Data : Undang- undang Perbankan Nomor 10 Tahun 1998.

\section{a. Tindak pidana yang berkaitan dengan perizinan}

Tindak pidana yang berkaitan dengan perizinan diatur dalam ketentuan pasal 46 Undang- undang Nomor 7 tahun 1992 yang diperbaharui dengan undang- undang Nomor 10 Tahun 1998.

Pasal 46

(1) Barang siapa menghimpun dana dari masyarakat dalam bentuk simpanan tanpa izin usaha dari pimpinan Bank Indonesia sebagaimana dimaksud dalam pasal 16, diancam dengan pidana penjara sekurang- kurangnya 5 tahun dan paling lama 15 tahun serta denda sekurang- kurangnya sepuluh milyar rupiah dan paling banyak dua ratus milyar rupiah.

(2) Dalam hal kegiatan sebagaimana dimaksud dalam ayat (1) dilakukan oleh badan hukum yang berbentuk perseroan terbatas, perserikatan, yayasan atau koperasi, maka penuntutan terhadap badan- badan dimaksud dilakukan baik terhadap mereka yang memberikan perintah melakukan perbuatan itu atau yang bertindak sebagai pimpinan dalam perbuatan itu atau terhadap kedua- duanya. 
Perumusan tindak pidana perbankan yang dimuat di dalam pasal 46 ayat (1) dan (2) Undang- undang Perbankan Nomor 10 Tahun 1998, dikatagorikan sebagai tindak pidana yang berkaitan dengan perizinan. Artinya, untuk mendirikan sebuah bank harus memenuhi persyaratan- persyaratan tertentu yang sudah ditetapkan, tidak bisa dilakukan secara sembarangan tanpa memenuhi persyaratan dan prosedur baku yang sudah digariskan. Persyaratan dimaksud diatur dalam ketentuan pasal 16, 18, 19 dan pasal 20 Undangundang Nomor 10 Tahun 1998.

\section{Pasal 16}

(1) Setiap pihak yang melakukan kegiatan menghimpun dana dari masyarakat dalam bentuk simpanan wajib terlebih dahulu memperoleh izin usaha sebagai bank umum atau bank perkreditan rakyat dari pimpinan Bank Indonesia, kecuali apabila kegiatan menghimpun dana dari masyarakat dimaksud diatur dengan Undangundang tersendiri.

(2) Untuk memperoleh izin usaha bank umum atau bank perkreditan rakyat sebagaimana dimaksud dalam ayat (1), wajib dipenuhi persyaratan seku-rangkurangnya adanya ;

a. Susunan organisasi dan kepengurusan,

b. Permodalan,

c. Kepemilikan,

d. Keahlian di bidang perbankan,dan

e. Kelayakan rencana kerja,

(3) Persyaratan dan tata cara perizinan bank sebagaimana dimaksud dalam ayat (2) ditetapkan oleh Bank Indonesia.

Berdasarkan ketentuan di atas, yang dapat dikenakan sanksi pidana dalam ke-tentuan pasal 46 ayat (1) Undang- undang Perbankan Nomor 10 Tahun 1998, adalah setiap orang (orang pada umumnya) yang menghimpun dana dari masyarakat dalam bentuk simpanan (rekening giro, tabungan, deposito berjangka) yang tidak memenuhi salah satu persyaratan yang ditetapkan dalam pasal 16, dan tidak memperoleh izin dari pimpinan Bank Indonesia, yang telah menjalankan fungsinya seolah- olah sebagai sebuah bank (dikatagorikan bank gelap). 


\section{b. Tindak pidana yang berkaitan dengan rahasia bank}

Persoalan rahasia bank sudah sejak lama menjadi isu krusial yang tak kunjung habis diperdebatkan oleh para ekonom, praktisi hukum, politikus, kalangan akade-misi dan masyarakat intelektual lainnya di Indonesia. Rahasia bank menjadi penting karena merupakan tonggak bagi kehidupan perbankan sebagai lembaga kepercayaan. Hanya saja, kehangatan dari pembahasan masalah rahasia bank tersebut mengalami pasang surut dan hasilnyapun kebanyakan masih pada tataran konseptual. Sekalipun ketentuan rahasia bank dalam Undang- undang perbankan telah diatur. Namun substansinya belum menyentuh titik keseimbangan antara berbagai kepentingan yang ada, sehingga format ideal tentang ketentuan rahasia bank yang diinginkan di Indonesia masih terus mencari bentuknya. ${ }^{5}$

Dalam mengantisipasi kelemahan rahasia bank yang cakupan materinya cukup luas termuat dalam pasal 1 angka 16 Undang- undang Perbankan Nomor 7 Tahun 1992 di atas, sehingga melahirkan adanya beberapa perubahan di dalam Undang- undang perbankan yang diperbaharui dengan Undang- undang Nomor 10 Tahun 1998, yang menyangkut pengaturan tentang 'rahasia bank'. Di dalam ketentuan pasal 1 angka 28 Undang- undang Perbankan Nomor 10 Tahun 1998, disebutkan : Rahasia bank adalah segala sesuatu yang berhubungan dengan keterangan mengenai nasabah penyimpan dan simpanannya. Pengertian rahasia bank yang termuat dalam pasal 1 angka 28 Undang- undang Perbankan Nomor 10 Tahun 1998 sangat sempit dan tidak terlalu luas yang wajib dirahasiakan sangat terbatas hanya pada penyimpan dan simpanannya (kreditur) dan tidak termasuk pinjaman/ kreditnya (debitur).

Persoalan kerahasiaan bank bukan hanya berlaku dalam lingkup nasional saja. Tetapi berlaku juga dalam lingkup regional dan internasional. Tiap negara yang satu dengan negara yang lain berbeda sistem yang dianutnya. Dalam teori kerahasiaan bank ini dapat dibedakan ke dalam 2 (dua) jenis, yaitu teori kerahasiaan bank yang bersifat absolut dan teori kerahasiaan bank yang bersifat nisbi. ${ }^{6}$

Kerahasiaan bank yang bersifat mutlak, artinya bank berkewajiban menyimpan rahasia keuangan nasabah atas simpanannya dalam keadaan dan atau kepentingan apapun yang sifatnya biasa ataupun luar biasa. Sedangkan kerahasiaan bank yang bersifat nisbi, bank berkewajiban menyimpan rahasia keuangan nasabah atas simpanannya dalam keadaan

${ }^{5}$ Yunus Husein, 2010, Rahasia Bank dan Penegakan Hukum, Pustaka Juanda Tiga Lima : Jakarta, Halaman 1.

${ }^{6}$ Rachmadi Usman, 2001, Aspek- aspek Hukum Perbankan di Indonesia, PT.Gramedia Pustaka Utama : Jakarta,Halaman 155. 
biasa, tetapi dalam hal- hal keadaan mendesak dan luar biasa, kerahasiaan dimaksud dikecualikan untuk motif- motif tertentu demi kepen-tingan negara. Teori kerahasiaan bank yang bersifat absolut/ mutlak lebih memen-tingkan individu, sehingga kepentingan masyarakat dan negara sering terabaikan. Sebaliknya teori kerahasiaan bank yang bersifat nisbi/ relatif lebih proporsional, dalam hal- hal tertentu kepentingan masyarakat dan negara lebih diutamakan ketimbang kepentingn individu.

Dari kedua teori kerahasiaan bank di atas, negara Indonesia terlihat menerapkan sistem kerahasiaan bank yang bersifat nisbi. Dalam arti, bank demi kepentingan masyarakat dan kepentingan negara dalam hal- hal tertentu dapat diinformasikan/ dibuka akses keuangan nasabah atas simpanannya. Sedangkan yang menerapkan sistem kerahasiaan bank yang bersifat absolut adalah bank- bank Swiss, dengan dalih/alasan- alasan apapun tidak dapat diterobos untuk mengungkapkan data kerahasiaan keuangan nasabah. Namun seiring dengan perjalanan waktu bank- bank Swisspun mulai mengalami perubahan dan atau pergeseran sistim kerahasiaan bank yang dianut yang bersifat nisbi (relatif) ketika adanya kesediaan Bank Swiss untuk memberikan dokumen yang berkaitan dengan kekayaan mantan Presiden Piliphina Marcos. ${ }^{7}$

Sebagaimana tindak pidana yang berkaitan dengan rahasia bank yang diatur dalam ketentuan pasal 47 Undang- undang Nomor 7 Tahun 1992 yang diperbaharui dengan undang- undang Nomor 10 Tahun 1998.

\section{Pasal 47}

(1) Barang siapa tanpa membawa perintah tertulis atau izin dari pimpinan Bank Indonesia sebagaimana dimaksud dalam pasal 41,41A, 42 dengan sengaja memaksa bank atau pihak terafiliasi untuk memberikan keterangan sebagaimana dimaksud dalam pasal 40, diancam dengan pidana penjara sekurang-kurangnya 2 tahun dan paling lama 4 tahun serta denda sekurang-kurangnya sepuluh milyar rupiah dan paling banyak dua ratus milyar rupiah.

(2) Anggota dewan komisaris, direksi, pegawai bank atau pihak teralifiasi lainnya yang dengan sengaja memberikan keterangan yang wajib diraha-sikan menurut pasal 40, diancam dengan pidana penjara sekurang- kurangnya 2 tahun dan paling lama 4 tahun serta denda sekurang- kurangnya empat milyar rupiah dan paling banyak delapan milyar rupiah.

${ }^{7}$ Muhammad Djumhana, Op, Cit, Halaman 165. 
Tindak pidana yang berkaitan dengan rahasia bank, selain sanksi pidananya dicantumkan dalam ketentuan pasal 47 ayat (1) dan (2), juga dicantumkan dan diatur dalam ketentuan pasal 47A Undang- undang Perbankan Nomor 10 Tahun 1998.

Pasal 47A

Anggota dewan komisaris, direksi atau pegawai bank yang dengan sengaja tidak memberikan keterangan yang wajib dipenuhi sebagaimana dimaksud dalam pasal $42 \mathrm{~A}$ dan pasal 44A, diancam dengan pidana penjara sekurang-kurangnya 2 tahun dan paling lama 7 tahun serta denda sekurang-kurangnya empat milyar rupiah dan paling banyak empat belas milyar rupiah.

Kerahasiaan keuangan nasabah penyimpan dana di bank yang masuk katagori pelanggaran hukum kepidanaan, dapat dikecualikan dan dibuka serta tidak diraha-siakan untuk kepentingan umum, seperti tertera pada tabel berikut ini ;

Tabel 2

Pengecualian- pengecualian Terhadap Rahasia Bank

\begin{tabular}{|l|l|l|}
\hline No. & \multicolumn{1}{|c|}{ Kepentingan } & \multicolumn{1}{c|}{ Pemberi Izin } \\
\hline 1 & Pajak & $\begin{array}{l}\text { Bank Indonesia atas permintaan Mente- } \\
\text { ri Keuangan }\end{array}$ \\
\hline 2 & Peradilan pidana & $\begin{array}{l}\text { Pimpinan Bank Indonesia (izin tertulis } \\
\text { atas permintaan tertulis dari polisi, jaksa } \\
\text { atau hakim) }\end{array}$ \\
\hline 3 & $\begin{array}{l}\text { Peradilan perdata antara bank dan } \\
\text { nasabahnya }\end{array}$ & $\begin{array}{l}\text { Direksi bank (menginformasikan ke- } \\
\text { pada pengadilan) }\end{array}$ \\
\hline 4 & $\begin{array}{l}\text { Tukar- menukar informasi antar } \\
\text { bank }\end{array}$ & $\begin{array}{l}\text { Direksi bank (memberitahukan kepada } \\
\text { bank lain) }\end{array}$ \\
\hline 5 & $\begin{array}{l}\text { Badan Urusan Piutang dan Lelang } \\
\text { Negara/Panitia Urusan Piutang } \\
\text { Negara }\end{array}$ & $\begin{array}{l}\text { Pimpinan Bank Indonesia (izin tertulis } \\
\text { atas permintaan tertulis dari kepala } \\
\text { BUPLN/PUPN }\end{array}$ \\
\hline 6 & $\begin{array}{l}\text { Pihak yang ditunjuk oleh nasabah } \\
\text { penyimpan dan/atau kuasanya } \\
\text { yang dibuat secara tertulis dan/ } \\
\text { atau permintaan ahli waris yang }\end{array}$ & $\begin{array}{l}\text { Bank tersebut (atas permintaan/perse- } \\
\text { tujuan atau kuasa tertulis dari nasabah } \\
\text { penyimpan) }\end{array}$ \\
\hline
\end{tabular}


sah dari nasabah penyimpan

Sumber Data : Undang- undang Perbankan Nomor 10 Tahun 1998.

Dari data yang tertera pada tabel di atas, ada beberapa pengecualian terhadap pemberlakuan rahasia bank, pengecualian tersebut dapat dibukanya rahasia bank demi kepentingan umum yang dapat berupa untuk kepentingan perpajakan, me-nyelesaikan piutang bank yang sudah diserahkan kepada BUPLN/PUPN, kepen-tingan peradilan dalam perkara pidana, perkara peradilan dalam perkara perdata antara bank dengan nasabah, tukar menukar informasi antar bank, permintaan nasa-bah penyimpan atau kuasanya yang dibuat secara tertulis dan permintaan ahli waris yang sah dari nasabah penyimpan. ${ }^{8}$ Pengecualianpengecualian dimungkinkan dapat dibukanya akses informasi mengenai keuangan nasabah penyimpan dana di bank dapat dilihat dalam ketentuan pasal 41, 41A, 42, 43,44 dan pasal 44A undang- undang Perbankan Nomor 10 Tahun 1998.

\section{c. Tindak pidana yang berkaitan dengan pengawasan dan pembinaan bank}

Pengawasan dan pembinaan bank dilakukan oleh Bank Indonesia sebagai bank sentral sangat penting artinya, sebagaimana diamanatkan oleh Undang- Undang Bank Indonesia Nomor 23 Tahun 1999 yang diperbaharui dengan Undang- undang Nomor 3 Tahun 2004. Kegiatan pembinaan dilakukan dengan cara menetapkan peraturan yang menyangkut aspek- aspek kelembagaan bank, kepemilikan bank, kepengurusan bank, kegiatan usaha bank, pelaporan bank dan lainnya yang berhu-bungan dengan operasional bank. Sedangkan kegiatan pengawasan dilakukan baik pengawasan yang dilakukan secara tidak langsung (off- site supervision) melalui penelitian analisis dan evaluasi laporan bank maupun pengawasan yang dilakukan secara langsung (on- site supervision) dalam bentuk pemeriksaan- pemeriksaan yang ditindak lanjuti dengan tindakan- tindakan perbaikan. Dengan demikan fungsi pembinaan lebih diarahkan kepada 'regulasi' dan fungsi pengawasan lebih menitik beratkan kepada 'supervisi'. 9

Tujuan pembinaan dan pengawasan bank yang dilakukan oleh Bank Indonesia adalah untuk menciptakan sistem perbankan yang sehat dan efisien, sehingga kesehatan bank tetap terjaga dan kepercayaan masyarakat terhadapnya tetap terpe-lihara. Di masa yang akan datang, tugas dan kewenangan dan tanggung jawab mengawasi bank tidak lagi dibawah kewenangan Bank Indonesia, akan tetapi berakhir kepada lembaga pengawasan sektor jasa

\footnotetext{
${ }^{8}$ Rachmadi Usman, 2001, Aspek- aspek Hukum Perbankan di Indonesia, PT. Gramedia Pustaka Utama : Jakarta, Halaman 156.

${ }^{9}$ Rachmadi Usman, $O p$, Cit, Halaman 122.
} 
keuangan. Hal ini sebagaimana diamanatkan dalam ketentuan pasal 35 Undang- undang Bank Indonesia Nomor 23 Tahun 1999 yang diperbaharui dengan Undang- undang Bank Indonesia Nomor 3 Tahun 2004, yang menyatakan bahwa tugas mengawasi bank akan dilakukan oleh lembaga pengawasan sektor jasa keuangan yang independen yang dibentuk dengan Undang- undang.

Undang-undang dimaksud yaitu dengan dikeluarkannya Undang- undang Nomor 21 Tahun 2011, yang mengatur tentang Otoritas Jasa Keuangan (OJK). Dalam melaksanakan tugasnya OJK melakukan kordinasi dan kerja sama dengan Bank Indonesia sebagai bank sentral. OJK dapat mengeluarkan ketentuan yang berkaitan dengan pelaksanaan tugas pengawasan bank yang dikordinasikan dengan Bank Indonesia dan meminta penjelasan dari Bank Indonesia, keterangan dan data yang diperlukan. Sedangkan tugas mengatur bank akan tetap dilakukan oleh Bank Indonesia. Dengan demikian akan terjadi pemisahan fungsi 'pembinaan dan penga-wasan' terhadap bank. Fungsi pembinaan tetap berada di tangan Bank Indonesia, sedangkan fungsi pengawasan diserahkan kepada OJK. ${ }^{10}$

Tingkat kesehatan bank wajib dipelihara dan dilakukan sedemikia rupa, sesuai dengan ketentuan yang berlaku dan wajib menyampaikan informasi yang dibu-tuhkan kepada Bank Indonesia dan wajib pula menyediakan informasi mengenai kemungkinan timbulnya risiko kerugian sehubungan dengan transaksi nasabah yang dilakukan melalui bank, berikut dengan memitigasi risiko dalam upaya pencegahan dan penanggulangannya. Kewajiban- kewajiban yang dibebankan pada bank harus dipenuhi sesuai dengan ketentuan yang berlaku, dengan cara menyampaikan laporan keuangan (neraca beserta laba rugi) dan lainnya yang sudah diaudit oleh kantor Akuntan Publik yang sudah tersertifikasi dan terdaptar di Bank Indonesia.

Kewajiban- kewajiban dalam hal pelaporan dan tindakan- tindakan lainnya yang lazim dalam dunia perbankan itu tidak dilakukan dengan baik oleh bank, baik karena unsur kesengajaan maupun karena unsur kelalaian yang dilakukan, yang tidak memenuhi kewajiban atau mematuhi ketentuan yang berlaku mengakibatkan bank (dewan komisaris, direksi dan pegawai bank) dapat dikenakan dan diterapkan ketentuan yang tertuang dalam pasal 48 Undang- undang Perbankan Nomor 7 Tahun 1992 yang diperbaharui dengan Undang- undang Perbankan Nomor 10 Tahun 1998.

Pasal 48

\footnotetext{
${ }^{10}$ Ibid, Halaman 127.
} 
(1) Anggota dewan komisaris, direksi atau pegawai bank yang dengan sengaja tidak memberikan keterangan yang wajib dipenuhi sebagaimana dimaksud dalam pasal 30 ayat (1) dan ayat (2) dan pasal 34 ayat (1) dan ayat (2), diancam dengan pidana penjara sekurang- kurangnya 2 tahun dan paling lama 10 tahun serta denda sekurang- kurangnya lima milyar rupiah dan paling banyak seratus milyar rupiah.

(2) Anggota dewan komisaris, direksi atau pegawai bank yang lalai membe-rikan keterangan yang wajib dipenuhi sebagaimana dimaksud dalam pasal 30 ayat (1) dan ayat (2) dan pasal 34 ayat (1) dan ayat (2), diancam dengan pidana kurungan sekurang- kurangnya 1 tahun dan paling lama 2 tahun dan atau denda sekurangkurangnya satu milyar rupiah dan paling banyak dua milyar rupiah.

Tindak pidana yang berkaitan dengan pengawasan dan pembinaan bank seba-gaimana dirumuskan dalam pasal 48 (1) Undang- undang Perbankan Nomor 10 Tahun 1998 di atas, dapat terjadi apabila adanya unsur kesengajaan yang dilakukan oleh anggota dewan komisaris, direksi dan pegawai bank yang telah melanggar ke-tentuan yang tertuang dalam pasal 30 ayat (1) dan (2) serta pasal 34 ayat (1) dan (2) Undang- undang Perbankan Nomor 10 Tahun 1998.

Pasal 30

(1) Bank wajib menyampaikan kepada Bank Indonesia, segala keterangan dan penjelasan mengenai usahanya menurut tata cara yang ditetapkan oleh Bank Indonesia.

(2) Bank atas permintaan Bank Indonesia, wajib memberikan kesempatan atas pemeriksaan buku- buku dan berkas- berkas yang ada padanya serta wajib memberikan bantuan yang diperlukan dalam rangka memperoleh kebenaran dari segala keterangan, dokumen dan penjelasan yang dilaporkan oleh bank yang bersangkutan.

Pasal 34

(1) Bank wajib menyampaikan kepada Bank Indonesia neraca dan perhitungan laba/rugi tahunan serta penjelasannya, serta laporan berkala lainnya dan waktu dan bentuk yang ditetapkan oleh Bank Indonesia. 
(2) Neraca serta perhitungan laba/rugi tahunan sebagaimana dimaksud dalam ayat (1) wajib terlebih dahulu diaudit oleh akuntan publik.

\section{d. Tindak pidana yang berkaitan dengan usaha bank}

Perbankan memiliki fungsi financial intermediary (perantara keuangan) dengan usaha pertama menghimpun dan menyalurkan dana masyarakat serta memberikan jasa- jasa lainnya dalam lalu lintas pembayaran. ${ }^{11}$ Dalam rangka menghimpun dan menyalurkan dana masyarakat serta menjalankan kegiatan jasa- jasa lainnya. Kegiatan usaha bank tidak boleh menyimpang dari ketentuan pasal 6 dan pasal 7 Undang- undang Perbankan Nomor 7 Tahun 1992 yang diperbaharui dengan Undang- undang Perbankan Nomor 10 Tahun 1998.

Sehubungan dengan usaha bank, anggota dewan komisaris, direksi atau pegawai bank yang dengan sengaja membuat pelaporan, melakukan pencatatan palsu dalam pembukuan dan dalam dokumen laporan kegiatan usaha, mengubah, mengaburkan, menyembunyikan, menghapus dan/ atau menghilangkan tidak memasukkan dalam laporan transaksi atau rekening dengan suatu itikad yang tidak baik, maka terhadap anggota dewan komisaris, direksi atau pegawai bank dianggap melakukan suatu tindak pidana yang berkaitan dengan usaha bank, sebagaimana yang dirumuskan dalam ketentuan pasal 49 Undang- undang Perbankan Nomor 10 Tahun 1998.

Pasal 49

(1) Anggota dewan komisaris, direksi atau pegawai bank yang dengan sengaja:

a. membuat atau menyebabkan adanya pencatatan palsu dalam pembu-kuan atau dalam laporan maupun dalam dokumen atau laporan kegiatan usaha, laporan transaksi atau rekening suatu bank,

b. menghilangkan atau tidak memasukkan atau menyebabkan tidak dilakukannya pencatatan dalam pembukuan atau dalam laporan maupun dalam dokumen atau laporan kegiatan usaha, laporan transaksi atau rekening suatu bank,

c. mengubah, mengaburkan, menyembunyikan, menghapus atau meng-hilangkan adanya suatu pencatatan dalam pembukuan atau dalam laporan maupun dalam dokumen atau laporang kegiatan usaha, laporan transaksi, atau rekening suatu bank, atau dengan sengaja mengubah, mengaburkan, mnghilangkan,menyembunyikan atau meru-sak catatan pembukuan tersebut, diancam dengan pidana penjara sekrang- kurangnya 5 tahun dan paling

\footnotetext{
${ }^{11}$ Rachmadi Usman, Op, Cit, Halaman 59.
} 
lama 15 tahun serta denda sekurang- kurangnya sepuluh milyar rupiah dan paling banyak dua ratus milyar rupiah.

(2) Anggota dewan komisaris, direksi atau pegawai bank yang dengan sengaja:

a. meminta atau menerima, mengizinkan atau menyetujui untuk menerima suatu imbalan, komisi, uang tambahan, pelayanan, uang atau barang berharga, untuk keuntungan rpibadinya atau untuk keuntungan keluarganya, dalam rangka mendapatkan atau berusaha mendapatkan bagi orang lain dalam memperoleh uang muka,bank garansi, atau fasilitas kredit dari bank, atau dalam rangka pembelian atau pendis-kontoan oleh bank atas surat- surat wesel,surat promes, cek dan kertas dagang atau bukti kewajiban lainnya, ataupun dalam rangka mem-berikan persetujuan bagi orang lain untuk melaksanakan penarikan dana yang melebihi batas kreditnya pada bank,

b. tidak melaksanakan langkah- langkah yang diperlukan untuk me-mastikan ketaatan bank terhadap ketentuan dalam undang- undang ini dan ketentuan peraturan perundang- undangan lainnya yang berlaku bagi bank, diancam dengan pidana penjara sekurang- kurangnya 3 tahun dan paling lama 8 tahun serta denda sekurang- kurangnya lima milyar rupiah dan paling banyak seratus milyar rupiah.

\section{e. Tindak pidana yang berkaitan dengan pihak teralifiasi}

Dalam menjalankan usaha bank, bukan hanya anggota dewan komisaris, direksi atau pegawai bank dituntut sikap tindak/perbuatan dengan penuh tanggung jawab dan menerapkan prinsif kehati- hatian serta mematuhi peraturan perundang- undangan yang berlaku, akan tetapi juga pihak teralifiasi dan pemegang saham. Apabila hal ini tidak diindahkan pasal 50 dan pasal 50A Undang- undang Perbankan Nomor 10 Tahun 1998 memberikan ancaman pidana terhadapnya.

Pasal 50

Pihak teralifiasi dengan sengaja tidak melaksanakan langkah- langkah yang diperlukan untuk memastikan ketaatan bank terhadap ketentuan dalam undangundang ini dan peraturan perundang- undangan lainnya yang berlaku bagi bank, diancam dengan pidana penjara sekurang- kurangnya 3 tahun dan paling lama 8 tahun serta denda sekurang- kurangnya lima milyar rupiah dan paling banyak seratus milyar rupiah. 


\section{Pasal 50A}

Pemegang saham dengan sengaja menyuruh dewan komisaris, direksi atau pegawai bank untuk melakukan atau tidak melakukan tindakan yang mengakibatkan bank tidak melaksanakan langkah- langkah yang diperlukan untuk memastikan ketaatan bank terhadap ketentuan dalam undang- undang ini dan ketentuan perundang- undangan lainnya yang berlaku bagi bank, diancam dengan pidana penjara sekurang- kurangnya 7 tahun dan paling lama 15 tahun serta denda sekurang-kurangnya sepuluh milyar rupiah dan paling banyak dua ratus milyar rupiah.

Pihak teralifiasi yang dimaksudkan dalam pasal 50 Undang- undang Perbankan Nomor 10 Tahun 1998, di dalam penjelasan pasal 1 angka 22 disebutkan ;

a. Anggota dewan komisaris, pengawas, direksi atau kuasanya, pejabat atau karyawan bank,

b. Anggota pengurus, pengawas, pengelola atau kuasanya, pejabat atau karyawan bank,

c. Pihak yang memberikan jasanya kepada bank, antara lain akuntan publik, penilai, konsultan hukum dan konsultan lainnya, dan

d. Pihak yang menurut penilaian Bank Indonesia turut serta mempengaruhi pengelolaan bank, antara lain pemegang saham dan keluarganya, keluarga komisaris, keluarga pengawas, keluarga direksi dan keluarga pengurus.

Para pihak yang dapat diancam pidana dalam pasal 50 Undang- undang Perban-kan Nomor 10 Tahun 1998 sangatlah luas sekali, baik yang menjalankan usaha bank secara langsung maupun secara tidak langsung yang meliputi dewan komisaris, pengawas, direksi, pejabat atau karyawan bank, anggota pengurus, anggota penga-was, anggota pengelola beserta kuasa- kuasanya dan pihak yang memberikan jasanya kepada bank, antara lain akuntan publik, penilai, konsultan hukum dan konsultan lainnya ataupun pihakpihak yang lainnya menurut penilaian Bank Indonesia turut serta mempengaruhi pengelolaan bank, antara lain keluarga pemegang saham, keluarga komisaris, keluarga pengawas, keluarga direksi dan keluarga pengurus, yang dengan sengaja tidak melaksanakan langkah- langkah yang diperlukan untuk memastikan ketaatan bank terhadap ketentuan dalam undang- undang ini dan peraturan perundang- undangan lainnya yang berlaku bagi bank. Diancam dengan pidana penjara sekurang- kurangnya 3 
tahun dan paling lama 8 tahun serta denda sekurang- kurangnya lima milyar rupiah dan paling banyak seratus milyar rupiah.

Di dalam ketentuan pasal 50A Undang- undang Perbankan Nomor 10 Tahun 1998,yang diancam pidana terbatas pada pemegang saham dengan sengaja menyu-ruh dewan komisaris, direksi atau pegawai bank untuk melakukan atau tidak melaku-kan tindakan yang mengakibatkan bank tidak melaksanakan langkah- langkah yang diperlukan untuk memastikan ketaatan bank terhadap ketentuan dalam undang- undang ini dan ketentuan perundang- undangan lainnya yang berlaku bagi bank. Persoalan pemegang saham tidak diatur dan dijelaskan secara rinci dalam Undang- undang Perbankan Nomor 10 Tahun 1998, tetapi dapat dilihat rujukannya dalam ketentuan pasal 1 angka 2 dan angka 4 Undang- undang Perseroan Terbatas Nomor 40 Tahun 2007.

Pasal 1

Angka 2 ; Organ perseroan adalah Rapat umum Pemegang Saham, Direksi dan Dewan Komisaris.

Angka 4; Rapat Umum Pemegang Saham adalah organ perseroan yang mempunyai wewenang yang tidak diberikan kepada Direksi atau dewan Komisaris dalam batas yang ditentukan dalam Undang- undang ini/atau Anggaran dasar.

Persoalan pengaturan pertanggung jawaban secara pidana terhadap pemegang saham menurut pasal 50A Undang- undang Perbankan Nomor 10 Tahun 1998,dapat dikenakan tindakan pidana minimal 7 tahun dan maksimal 15 tahun dan atau denda minimal sepuluh milyar rupiah dan maksimal dua ratus milyar rupiah. Sudah tepat-kah jika dihubungkan dengan ketentuan pasal 3 ayat (1) Undang- undang Perseroan Terbatas Nomor 40 Tahun 2007, yang menyatakan pemegang saham perseroan tidak bertanggung jawab secara pribadi atas perikatan yang dibuat atas nama perseroan dan tidak bertanggung jawab atas kerugian perseroan melebihi saham yang dimiliki. Kenyataan menunjukkan ketentuan yang termuat dalam pasal 3 ayat (1) Undang- undang Perseroan Terbatas Nomor 40 Tahun 2007 dikesampingkan dengan diakomodirnya ketentuan pasal 50A Undang- undang Perbankan Nomor 10 Tahun 1998, yang menganut prinsif piercing the corporate veil atau pertanggung jawaban dapat dimintakan sampai kepada harta pribadi yang bersangkutan sebagaimana yang dikuatkan dalam perumusan pasal 3 ayatb (2) hurup a sampai dengan 
hurup d Un-dang- undang Perseroan Terbatas Nomor 40 Tahun 2007, yang menyatakan ; a. persyaratan perseroan sebagai badan hukum tidak terpenuhi, b. Pemegang saham yang bersangkutan baik langsung maupun tidak langsung dengan itikad buruk memanfaatkan perseroan untuk kepentingan pribadi, c. Pemegang saham yang bersangkutan terlibat dalam perbuatan melawan hukum yang dilakukan oleh perseroan dan d. Pemegang saham yang bersangkutan baik langsung maupun tidak langsung secara melawan hukum menggunakan kekayaan perseroan sehingga kekayaan perseroan menjadi tidak cukup untuk melunasi hutang perseroan.

Dari berbagai jenis tindak pidana perbankan yang diutarakan di atas, yaitu tindak pidana yang berkaitan dengan perizinan, tindak pidana yang berkaitan dengan rahasia bank, tindak pidana yang berkaitan dengan pengawasan dan pembinaan bank, tindak pidana yang berkaitan dengan usaha bank serta tindak pidana yang berkaitan dengan pihak teralifiasi, yang diatur dalam ketentuan pasal 46 hingga pasal 50A, dapat dilihat jenisnya dalam bentuk tabel berikut ini ;

\section{Tabel 3}

\section{Perbuatan dan Sanksi Pidana Yang Dirumuskan Dalam Pasal 46 Hingga Pasal 50A Undang- undang Perbankan Nomor 10 Tahun 1998}

\begin{tabular}{|c|c|c|c|}
\hline No & Pasal & Perbuatan Pidana & Sanksi Pidana \\
\hline 1 & 46 ayat $(1)$ & $\begin{array}{l}\text { 1.Tindak pidana yang berkaitan dengan } \\
\text { perizinan; } \\
\text { a.menghimpun dana masyarakat da- } \\
\text { lam bentuk simpanan, dan } \\
\text { b.tanpa izin usaha dari pimpinan Bank } \\
\text { Indonesia (sebagaimana dimaksud } \\
\text { dalam pasal 16). }\end{array}$ & $\begin{array}{l}\text { Pidana penjara } \\
\text { 5-15 tahun, dan } \\
\text { Denda10-200 milyar } \\
\text { rupiah. }\end{array}$ \\
\hline & ayat (2) & $\begin{array}{l}\text { a. kegiatan dalam ayat (1), dan } \\
\text { b.dilakukan oleh badan hukum (ber- } \\
\text { bentuk PT, perserikatan,yayasan, ko- } \\
\text { perasi). }\end{array}$ & $\begin{array}{l}\text { Penentuan terhadap ; } \\
\text { a.yang memberi pe- } \\
\text { rintah, } \\
\text { b.pimpinan dalam } \\
\text { perbuatan itu, } \\
\text { c.kedua- keduanya }\end{array}$ \\
\hline
\end{tabular}




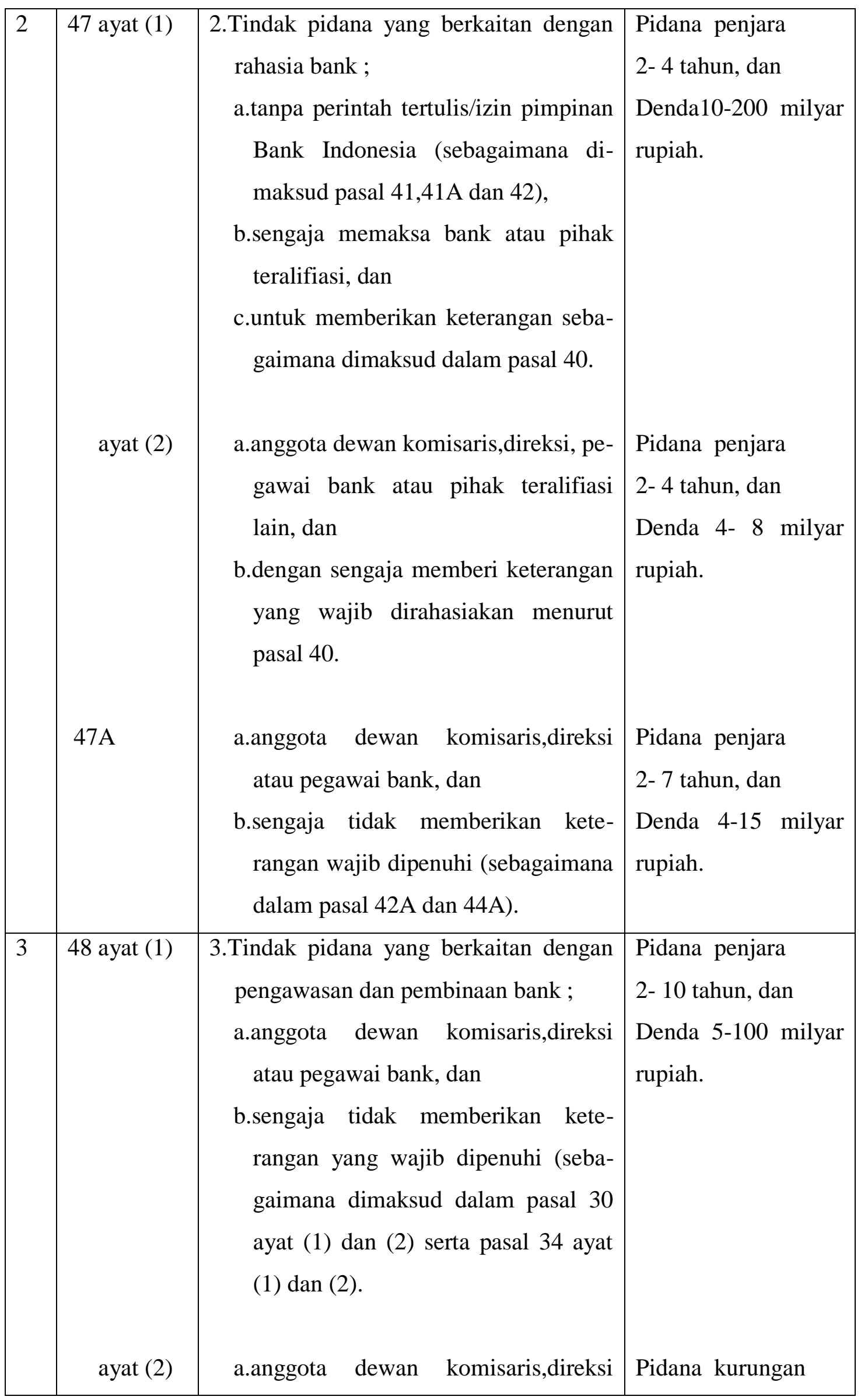




\begin{tabular}{|c|c|c|c|}
\hline & & $\begin{array}{l}\text { atau pegawai bank, dan } \\
\text { b.lalai memberikan keterangan yang } \\
\text { wajib dipenuhi (sebagaimana dimak- } \\
\text { sud pasal } 30 \text { ayat (1) dan (2) serta } \\
\text { pasal } 34 \text { ayat (1) dan (2). }\end{array}$ & $\begin{array}{l}\text { 1- } 2 \text { tahun, dan } \\
\text { Denda } 1-2 \text { milyar } \\
\text { rupiah. }\end{array}$ \\
\hline 4 & 49 ayat (1) & $\begin{array}{l}\text { 4.Tindak pidana yang berkaitan dengan } \\
\text { usaha bank; } \\
\text {-Anggota dewan komisaris,direksi atau } \\
\text { pegawai bank yang sengaja ; } \\
\text { a.membuat/menyebabkan adanya pen- } \\
\text { catatan palsu dalam pembukuan/ la- } \\
\text { poran, dalam dokumen/laporan ke- } \\
\text { giatan usaha,laporan transaksi, atau } \\
\text { rekning suatu bank, } \\
\text { b.menghilangkan,tidak memasukkan, } \\
\text { atau menyebabkan tidak dilakukan- } \\
\text { nya pencatatan dalam pembukuan/ } \\
\text { laporan,dalam dokumen/laporan ke- } \\
\text { giatan usaha,laporan transaksi atau } \\
\text { rekening suatu bank, dan } \\
\text { c.mengubah,mengaburkan, menyem- } \\
\text { bunyikan,menghapus atau menghi- } \\
\text { langkan adanya pencatatan dalam } \\
\text { pembukuan/laporan,dalam dokumen } \\
\text { /laporan kegiatan usaha,laporan } \\
\text { transaksi atau rekening suatu bank ; } \\
\text { atau dengan sengaja mengubah, } \\
\text { mengaburkan, menghilangkan, me- } \\
\text { nyembunyikan atau merusak catatan } \\
\text { pembukuan tersebut. }\end{array}$ & $\begin{array}{l}\text { Pidana penjara } \\
5-15 \text { tahun, dan } \\
\text { Denda10-200 milyar } \\
\text { rupiah. }\end{array}$ \\
\hline & Ayat (2) & $\begin{array}{l}\text {-Anggota dewan komisaris.direksi atau } \\
\text { pegawai bank yang dengan sengaja ; }\end{array}$ & $\begin{array}{l}\text { Pidana penjara } \\
\text { 3- } 8 \text { tahun, dan }\end{array}$ \\
\hline
\end{tabular}




\begin{tabular}{|c|c|c|c|}
\hline & & $\begin{array}{l}\text { a.meminta/menerima, mengizinkan/ } \\
\text { menyetujui untuk menerima suatu } \\
\text { imbalan,komisi,uang tambahan, pe- } \\
\text { layanan,uang/barang berharga, un- } \\
\text { tuk keuntungan pribadi/ keluar- } \\
\text { ganya, dalam rangka mendapatkan } \\
\text { atau berusaha mendapatkan uang } \\
\text { muka,bank garansi atau fasilitas kre- } \\
\text { dit dari bank, atau dalam rangka } \\
\text { pembelian atau pendiskontoan oleh } \\
\text { bank atas surat-surat wesel, surat } \\
\text { promes,cek dan kertas dagang atau } \\
\text { bukti kewajiban lainnya atau dalam } \\
\text { rangka memberikan persetujuan bagi } \\
\text { orang lain untuk melaksanakan } \\
\text { penarikan dana yang melebihi batas } \\
\text { kreditnya, dan } \\
\text { b.tidak melaksanakan langkah- lang- } \\
\text { kah yang diperlukan untuk memasti- } \\
\text { kan ketaatan bank terhadap keten- } \\
\text { tuan dalam undang- undang ini dan } \\
\text { peraturan perundang-undangan lain- } \\
\text { nya yang berlaku bagi bank. }\end{array}$ & $\begin{array}{l}\text { Denda 5-100 milyar } \\
\text { rupiah. }\end{array}$ \\
\hline 5 & 50 & $\begin{array}{l}\text { 5.Tindak pidana yang berkaitan dengan } \\
\text { pihak teralifiasi ; } \\
\text { a.pihak teralifiasi, } \\
\text { b.dengan sengaja, dan } \\
\text { c.tidak melaksanakan langkah-langkah } \\
\text { yang diperlukan untuk memastikan } \\
\text { ketaatan bank terhadap ketentuan da- } \\
\text { lam undang- undang ini dan peratu- } \\
\text { ran perundang-undangan lainnya yang } \\
\text { berlaku bagi bank. }\end{array}$ & $\begin{array}{l}\text { Pidana penjara } \\
\text { 3- } 8 \text { tahun, dan } \\
\text { Denda 5-100 milyar } \\
\text { rupiah. }\end{array}$ \\
\hline
\end{tabular}




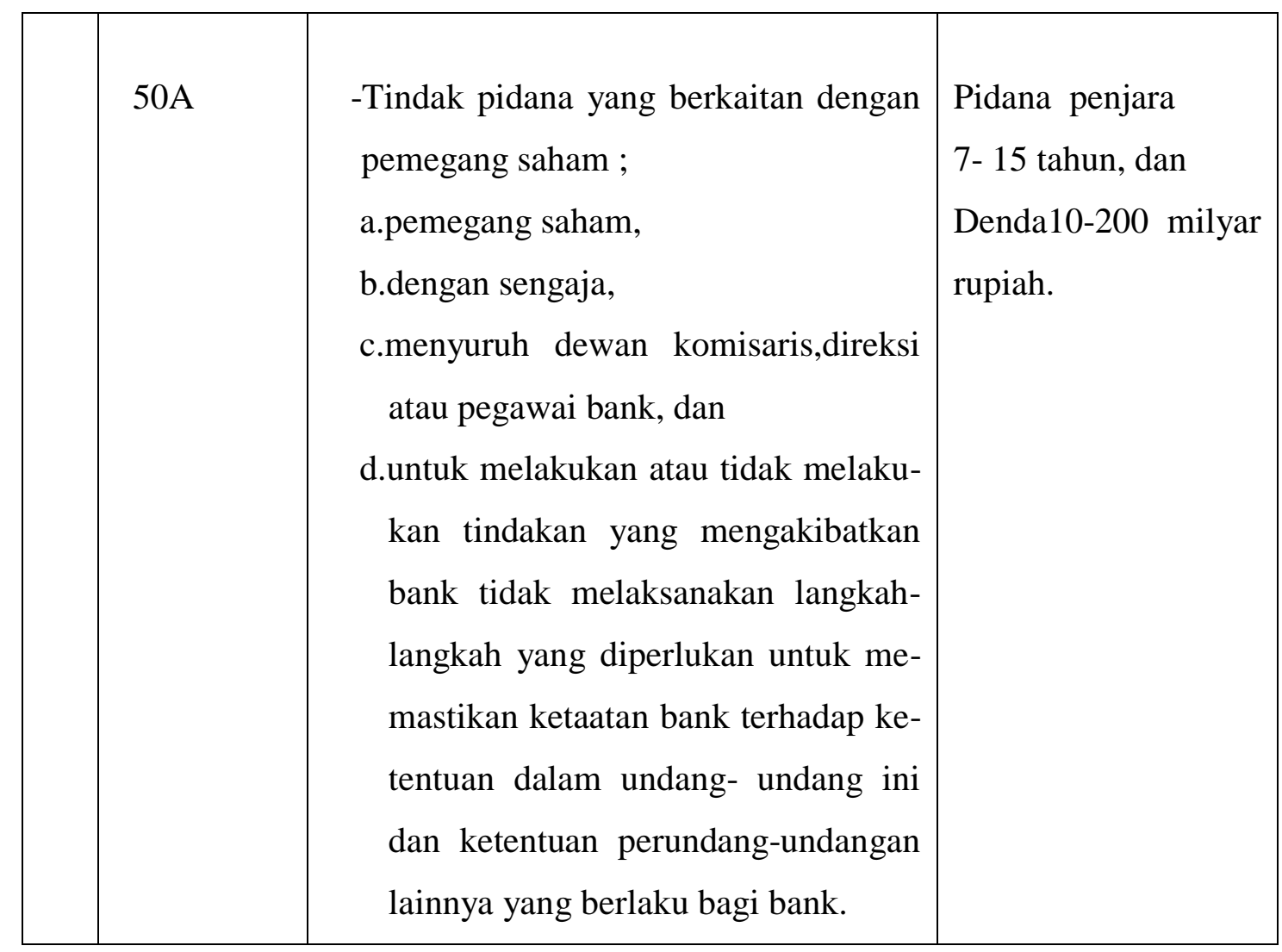

Sumber Data : Diolah dari Undang- undang Perbankan Nomor 10 Tahun 1998.

Apabila ditelusuri dan ditelaah ketentuan yang terdapat dalam rumusan pasal 46, pasal 47, pasal 47A, pasal 48, pasal 49, pasal 50 dan pasal 50A Undang- undang Perbankan Nomor 7 Tahun 1992 yang diperbaharui dengan undang- undang Nomor 10 Tahun 1998, di mana didalamnya dapat dibedakan dan atau diklasifikasikan suatu perbuatan/tindak pidana yang berupa kejahatan dan tindak pidana yang berupa pelanggaran, ${ }^{12}$ seperti terlihat perbedaannya pada tabel berikut ini ;

\section{Tabel 4}

\section{Penggolongan Tindak Pidana Perbankan Yang Berupa Kejahatan dan Pelanggaran Dalam Undang- undang Perbankan Nomor 10 Tahun 1998}

\begin{tabular}{|c|l|l|}
\hline No & \multicolumn{1}{|c|}{$\begin{array}{c}\text { Penggolongan Tindak } \\
\text { Pidana Perbankan }\end{array}$} & \multicolumn{1}{c|}{ Kreteria Perbedaan } \\
\hline 1 & Kejahatan & $\begin{array}{l}\text { 1. Perbuatan dilakukan dengan unsur sengaja } \\
\text { 2. Ancaman pidana penjara dan denda } \\
\end{array}$ \\
& & 3. Pelanggaran pasal 46, 47, 47A, 48 ayat (1), \\
\hline
\end{tabular}

\footnotetext{
${ }^{12}$ Hermansyah, Op, Cit, Halaman 151.
} 


\begin{tabular}{|c|c|c|}
\hline & & 49,50 dan pasal 50A. \\
\hline 2 & Pelanggaran & $\begin{array}{l}\text { 1. Perbuatan dilakukan dengan unsur kealpa- } \\
\text { an dan/atau kelalaian } \\
\text { 2. Ancaman pidana kurungan dan denda } \\
\text { 3. Pelanggaran pasal } 48 \text { ayat (2). }\end{array}$ \\
\hline
\end{tabular}

Sumber Data : Diolah dari Undang- undang Perbankan Nomor 10 Tahun 1998.

Perbedaan antara kejahatan dan pelanggaran pada umumnya dapat dibedakan berdasarkan pembedaan kualitatif dan kuantitatif. Perbedaan kualitatif didasarkan kepada kreteria sikap bathin/unsur subjektif yaitu yang berupa unsur perbuatan kesengajaan dikatagorikan perbuatan kejahatan dan unsur perbuatan kealpaan/ kelalaian dikatagorikan melakukan perbuatan pelanggaran. Sedangkan perbedaan dilihat dari segi kuantitatif diukur dari kreteria soal berat dan ringannya ancaman pidana, jika perbuatan tergolong kejahatan diancam pidana penjara dan denda dan untuk perbuatan yang tergolong pelanggaran diancam dengan pidana kurungan dan denda. Penggolongan antara tindak pidana yang berupa kejahatan dengan berupa pelanggaran dicantumkan dalam pasal 51 Undang- undang Perbankan Nomor 10 Tahun 1998.

Pasal 51

(1) Tindak pidana sebagaimana dimaksud dalam pasal 46, 47, pasal 47A, pasal 48 ayat (1), 49, 50 dan pasal 50A adalah kejahatan.

(2) Tindak pidana sebagaimana dimaksud dalam pasal 48 ayat (2) adalah pelanggaran.

Selain dapat diterapkan/ dikenakan ancaman pidana terhadap dewan komisaris, direksi, pegawai bank dan pihak teralifiasi lainnya, maka dalam Undang- undang Perbankan Nomor 7 Tahun 1992 yang diperbaharui dengan Undang- Undang Nomor 10 Tahun 1998 dikenal juga adanya sanksi administratif selain sanksi pidana. Sanksi administratif yang berupa sanksi yang dapat diberikan oleh Bank Indonesia (sekarang Otoritas Jasa Keuangan) dengan berbagai bentuk sanksi administratif seperti terlihat dalam tabel berikut ini ;

\section{Tabel 5}

\section{Jenis Sanksi Dalam Undang- undang Perbankan Nomor 10 Tahun 1998}




\begin{tabular}{|l|l|l|}
\hline No & $\begin{array}{c}\text { Jenis Sanksi Dalam Undang- } \\
\text { undang Perbankan }\end{array}$ & \multicolumn{1}{c|}{ Kreteria Perbedaan Sanksi } \\
\hline 1 & Sanksi pidana & $\begin{array}{l}\text { 1. Pidana penjara minimal } 2 \text { tahun dan } \\
\text { maksimal } 15 \text { tahun } \\
\text { 2. Pidana kurungan minimal } 1 \text { tahun dan } \\
\text { maksimal } 2 \text { tahun }\end{array}$ \\
\hline 2 & Sanksi administratif & $\begin{array}{l}\text { 3. Pidana denda minimal } 4 \text { milyar dan } \\
\text { maksimal } 200 \text { milyar rupiah }\end{array}$ \\
& $\begin{array}{l}\text { 1. Denda uang } \\
\text { 2. Teguran tertulis } \\
\text { 3. Penurunan tingkat kesehatan bank } \\
\text { 4. Larangan untuk turut serta dalam kegiatan } \\
\text { kliring } \\
\text { 5. Pembekuan kegiatan usaha tertentu } \\
\text { 6. Pemberhentian pengurus bank } \\
\text { 7. Pencantuman anggota pengurus, pegawai } \\
\text { bank dan pemegang saham dalam daptar } \\
\text { orang tercela (black list) }\end{array}$ \\
\hline
\end{tabular}

Sumber Data : Diolah dari Undang- undang Perbankan Nomor 10 Tahun 1998.

Apabila ditelaah dari data yang terdapat di dalam tabel di atas, terlihat jenis sanksi yang ada di dalam Undang- undang Perbankan Nomor 10 Tahun 1998, yang dapat dibedakan ke dalam golongan baik sanksi pidana maupun sanksi administratif sebagaimana yang diatur dalam ketentuan pasal 52 Undang- undang Perbankan Nomor 10 Tahun 1998.

Pasal 52

(1) Dengan tidak mengurangi ketentuan pidana sebagaimana dimaksud dalam pasal 47, pasal 47A, pasal 48, 49 dan pasal 50A, Bank Indonesia dapat menetapkan sanksi administratif kepada bank yang tidak memenuhi kewajibannya sebagaimana dimaksud dalam Undang- undang ini, atau pimpinan Bank Indonesia mencabut izin usaha bank yang bersangkutan.

(2) Sanksi administratif sebagaimana dimaksud dalam ayat (1), antara lain adalah

a. denda uang, 
b. teguran tertulis,

c. penurunan tingkat kesehatan bank,

d. larangan untuk turut serta dalam kegiatan kliring,

e. pembekuan kegiatan usaha tertentu, baik untuk kantor cabang terten-tu maupun untuk bank secara keseluruhan,

f. pemberhentian pengurus bank dan selanjutnya menunjuk dan mengangkat pengganti sementara sampai Rapat Umum Pemegang Saham mengangkat pengganti yang tetap dengan persetujuan Bank Indonesia, dan

g. pencantuman anggota pengurus, pegawai bank, pemegang saham dalam daptar orang tercela di bidang perbankan.

(3) Pelaksanaan lebih lanjut mengenai sanksi administratif ditetapkan oleh Bank Indonesia.

Dewan komisaris, direksi, pegawai bank dan lainnya, di samping dapat dite-rapkan ancaman sanksi pidana sebagaimana diatur dalam ketentuan pasal 46, 47, 48, 49 dan pasal 50 Undang- undang Perbankan Nomor 10 Tahun 1998, maka Bank Indonesia dapat pula menerapkan sanksi administratif terhadap pihak bank ataupun pihak teralifiasi yang melakukan penyimpangan- penyimpangan dalam menjalankan kegiatan operasional bank sesuai dengan ketentuan pasal 52 Undang- undang Perbankan Nomor 10 Tahun 1998.

Penerapan sanksi administratif yang dapat diberikan dan/atau dijatuhkan oleh Bank Indonesia (sekarang Otoritas Jasa Keuangan) kepada bank yang melanggar ketentuan pasal 52 ayat (2) Undang- undang Perbankan Nomor 7 Tahun 1992 yang diperbaharui dengan Undang- undang Nomor 10 Tahun 1998, dapat berbentuk sanksi administratif berupa denda uang, memberikan teguran secara tertulis, melakukan penurunan tingkat kesehatan bank, larangan untuk turut serta dalam kegiatan kliring, pembekuan kegiatan usaha tertentu, baik untuk kantor cabang tertentu maupun untuk bank secara keseluruhan dan pemberhentian pengurus bank (anggota dewan komi-saris dan/ atau direksi) dan selanjutnya menunjuk dan mengangkat pengganti semen-tara (anggota dewan komiaris dan/ atau direksi bank) sampai adanya Rapat Umum Pemegang Saham untuk mengangkat pengganti yang tetap dengan persetujuan Bank Indonesia, dan pencantuman anggota pengurus, pegawai bank, pemegang saham dalam daptar orang tercela (black list) di bidang perbankan. 


\section{Kebijakan Regulasi Yang Termuat Di luar Undang- Undang Perbankan Nomor 10 Tahun 1998.}

Tindak pidana perbankan yang berkaitan dengan perizinan untuk mendirikan bank sebagaimana yang diatur dalam ketentuan pasal 46, yang berkaitan dengan rahasia bank yang menyangkut rahasia keuangan nasabah penyimpan dan sim-panannya yang diatur dalam ketentuan pasal 47 dan pasal 47A, pengawasan dan pembinaan bank yang diatur di dalam ketentuan pasal 48, yang berkaitan dengan usaha bank sebagaimana yang diatur dan dirumuskan dalam ketentuan pasal 49 dan tindak pidana yang berkaitan dengan pihak teralifiasi seperti yang diatur dalam ketentuan pasal 50 dan pasal 50A. Kesemua jenis tindak pidana perbankan di atas, di samping diatur di dalam ketentuan Undang- Undang Perbankan Nomor 7 Tahun 1992 sebagaimana yang diperbaharui dengan dengan UndangUndang Nomor 10 Tahun 1998, maka tindak pidana yang berhubungan dengan kegiatan operasional perbankan diatur pula dan tersebar di berbagai peraturan perundang- undangan lain-nya yang berlaku, seperti terlihat dalam tabel berikut ini ;

\section{Tabel 6}

\section{Tindak Pidana Yang Berkaitan Dengan Kegiatan Perbankan di Luar Undang- undang Perbankan Nomor 10 Tahun 1998}

\begin{tabular}{|l|l|l|}
\hline No & \multicolumn{1}{|c|}{$\begin{array}{c}\text { Tindak Pidana Yang Berkaitan } \\
\text { Dengan kegiatan Perbankan }\end{array}$} & \multicolumn{1}{c|}{ Pasal } \\
\hline 1 & $\begin{array}{l}\text { Kitab Undang- undang Hukum Pidana (KUHP) } \\
\text { Nomor 1 Tahun 1946 }\end{array}$ & $\begin{array}{l}\text { Pasal 263, 264, 362, 363, } \\
\text { 372, 374 dan pasal 378. }\end{array}$ \\
\hline 2 & $\begin{array}{l}\text { Undang- undang Pemberantasan Tindak Pidana } \\
\text { Korupsi Nomor 31 Tahun 1999 yang diperbaha- } \\
\text { rui dengan Undang- undang Nomor 20 Tahun } \\
\text { 2001 }\end{array}$ & $\begin{array}{l}\text { Pasal 2 dan pasal 3, pasal 4, } \\
\text { pasal 5, pasal 18 ayat (1). }\end{array}$ \\
\hline 3 & $\begin{array}{l}\text { Undang- undang Penanaman Modal Nomor 8 } \\
\text { Tahun 1995 }\end{array}$ & Pasal 103 ayat (1) \\
\hline 4 & $\begin{array}{l}\text { Undang- undang Pencegahan dan Pemberanta- } \\
\text { san Tindak Pidana Pencucian Uang Nomor 25 } \\
\text { Tahun 2003 yang diperbaharui dengan Undang- } \\
\text { undang Nomor 8 Tahun 2010 }\end{array}$ & Pasal 3, 4 dan pasal 5. \\
\hline
\end{tabular}




\begin{tabular}{|l|l|l|}
\hline 5 & Undang- undang Informasi dan Transaksi Elek- & Pasal 46 ayat (1) dan (3), \\
tronik Nomor 11 Tahun 2008 & $\begin{array}{l}\text { pasal 48 ayat (2), dan pasal } \\
51 \text { ayat (2). }\end{array}$ \\
\hline 6 & $\begin{array}{l}\text { Undang- undang Transper Dana Nomor 3 Tahun } \\
\text { Pasal 79, 81, 83 dan pasal } \\
84 .\end{array}$ \\
\hline
\end{tabular}

Sumber Data : Diolah Dari Berbagai Undang- undang Yang Berkaitan Dengan Kegiatan Perbankan.

Ditelaah data yang tertuang dalam tabel di atas, terlihat juga ada beberapa tindak pidana yang terkait dengan kegiatan operasional perbankan yang berada dan terdapat di luar Undang- undang Perbankan Nomor 7 Tahun 1992 yang diperbaharui dengan Undangundang Nomor 10 Tahun 1998, yaitu yang terdapat dan termuat di dalam Kitab Undangundang Hukum Pidana (KUHP) Nomor 1 Tahun 1946 dan Undang- undang Pemberantasan Tindak Pidana Korupsi Nomor 31 Tahun 1999 yang diperbaharui dengan Undang- undang Nomor 20 Tahun 2001.

Peraturan perundang- undangan lainnya yang berkaitan dengan tindak pidana di bidang perbankan, diatur pula ketentuannya di dalam Undang- undang Pasar Modal Nomor 8 Tahun 1995, Undang- Undang- undang Pencegahan dan Pemberantasan Tindak Pidana Pencucian Uang Nomor 25 Tahun 2003 yang diperbaharui dengan Undang- undang Nomor 8 Tahun 2010, Undang- undang Informasi dan Transaksi Elektronik Nomor 11 Tahun 2008 dan termasuk pula Undang- undang Transper Dana Nomor 3 Tahun 2011.

\section{Beberapa Faktor Yang Merupakan Penghambat Dalam Penanggulangan Tindak Pidana di Bidang Perbankan}

Tindak pidana di bidang perbankan yang terjadi selama ini pada umumnya melibatkan orang dalam bank (pihak intern/pihak teralifiasi) yang tentu-nya mengetahui mekanisme, prosedur dan sistem keamanan bank yang bersangkutan. Keterlibatan orang dalam bank ini, ada yang memang murni inisiatif sendiri dan ada kerja sama antar orang dalam, ada juga kolaborasi antara orang dalam bank dengan orang di luar bank (ektern), dan atau bahkan benar- benar pembobolan yang dila-kukan oleh orang luar bank dengan merusak 
sistem keamanan bank, dengan menggu-nakan pencurian data melalui hackers dengan fasilitas internet banking. ${ }^{13}$

Modusnya, penipuan dan pembobolan uang diduga dilakukan hackers dengan menggunakan malware (malicius sofware). Malware yaitu sofware yang dibuat, digunakan untuk membobol rekening bank atau menjebol data oleh hackers. Pelaku menggunakan malware ini untuk mengalihkan nasabah bank yang mengakses laman perbankan elektronik atau e-banking ke laman palsu milik hackers. Saat ada korban yang mentransper sejumlah uang melalui e-banking, pelaku mengalihkan nomor rekening tujuan ke nomor rekening kurir tanpa diketahui korban. Dari rekening kurir uang dikirim ke Ukraina lewat western union dan moneygram. ${ }^{14}$

Dalam implementasi penerapan hukum pidana, sudah banyak kasus- kasus tindak pidana di bidang perbankan yang diproses dan diselesaikan secara hukum, yang dimulai dari tahap penyelidikan, penyidikan, penuntutan dan sampai di sidang-kan di pengadilanpengadilan di seluruh wilayah Indonesia. Namun demikian, tak dapat dipungkiri tindak pidana di bidang perbankan berkembang terus dan menun-jukkan trend yang meningkat dengan berbagai modus operandi yang bervariasi. Hal ini dapat terjadi dalam tataran praktiknya yang disebabkan ada beberapa faktor peng-hambat, Dengan menggunakan 'teori sistem hukum' yang digagas oleh Lawrence M. Friedman, hambatan itu dapat dilihat dari bekerjanya hukum yang dapat ditelaah dari 3 (tiga) aspek, ${ }^{15}$ yaitu :

a. Legal substance (substansi hukum) yaiu hasil aktual yang diterbitkan/ dike-luarkan oleh sistem hukum (berupa norma- norma hukum yang berupa pera-turanperaturan dan lainnya) yang digunakan oleh aparat penegak hukum,

b. Legal structure (struktur hukum) yang suatu bagian- bagian yang bergerak di dalam suatu mekanisme atau kelembagaan yang diciptakan oleh sistem hu-kum dan berfungsi untuk mendukung bekerjanya sistem hukum, dan

c. Legal culture (budaya hukum) yang berupa ide- ide, sikap, harapan dan pendapat tentang hukum sebagai keseluruhan faktor yang mementukan bagai-mana sistem hukum memperoleh tempatnya,bagaimana orang menerima hu-kum atau sebaliknya.

\footnotetext{
${ }^{13}$ Sutan remy Sjahdeini, 2006, Himpunan Tulisan Kapita Selekta Hukum Perbankan, UI Press : Ja-karta, Halaman 20.

${ }^{14}$ Ibid.

${ }^{15}$ Arief Hidayat, Juli 2009, Menegaskan Kembali Peran Negara di Tengah Melemahnya Kedau-latan Negara di Era Global dimuat dalam Buku Bunga Rampai Potret Penegakan Hukum di Indonesia, Komisi Yudisial RI : Jakarta, Halaman 49.
} 
Ketiga sistem hukum di atas, saling terkait dan mempengaruhi satu dengan yang lainnya dalam upaya penanggulangan tindak pidana di bidang perbankan, dilihat dari legal substance (substansi hukum) yang berupa peraturan perundang- undangan Perbankan Nomor 7 Tahun 1992 yang diperbaharui dengan Undang- undang Nomor 10 Tahun 1998 yang norma- norma hukumnya termuat dalam peraturan masih ku-rang jelas, sangat terbatas dan belum sepenuhnya mampu mengatasi tindak pidana perbankan yang terjadi dalam tataran praktiknya. Begitu juga legal structure (struk-tur hukum) yang menyangkut struktur/kelembagaan yang melibatkan aparat penegak hukum kepolisian, kejaksaan, hakim pengadilan, lembaga pemasyarakatan dan ter-masuk advocat/ penasehat hukum, terlihat belum harmonisasi dan sinkronisasi antar aparat penegak hukum dalam hal penyelidikan dan penyidikan dan termasuk keter-batasan kemampuan, sarana dan prasarana pendukung dalam upaya penanggulangan tindak pidana di bidang perbankan. Didukung pula oleh legal culture (budaya hu-kum) yang dipraktikkan dalam penegakan hukum dengan prilaku yang kurang baik dalam penerapan pidana terhadap pelaku tindak pidana di bidang perbankan, se-hingga hal inilah yang menjadi penghambat belum maksimalnya dalam upaya pe-nanggulangan tindak pidana di bidang perbankan.

\section{Dilihat Dari Aspek Substansi Peraturan Perundang- undangan}

Undang- undang Perbankan Nomor 7 Tahun 1992 yang diperbaharui dengan Un-dangundang Nomor 10 Tahun 1998, di mana di dalamnya diatur beberapa jenis tindak pidana perbankan mulai dari ketentuan pasal 46 hingga pasal 50A, yaitu tin-dak pidana yang berkaitan dengan perizinan (pasal 46), tindak pidana yang ber-kaitan dengan rahasia bank (pasal 47), tindak pidana berkaitan dengan pengawasan dan pembinaan bank (pasal 48), tindak pidana yang berkaitan dengan usaha bank (pasal 49) serta tindak pidana yang berkaitan dengan pihak teralifiasi (pasal 50).

Ditelusuri dan ditelaah substansi/materi pasal- pasal yang termuat di dalam Undangundang Perbankan Nomor 7 Tahun 1992 yang diperbaharui dengan Un-dang- undang Nomor 10 Tahun 1998, terlihat substansi/materi yang terkandung di dalam Undangundang perbankan masih belum optimal dalam upaya penanggu-langan tindak pidana perbankan. Hal ini terlihat dari beberapa pasal dalam Undang- undang perbankan terkait dengan ketentuan yang tertuang dalam pasal 46 ayat (2) Undang- undang Perbankan Nomor 10 Tahun 1998, terlihat masih menimbulkan persoalan dan mengandung kelemahan. 
Pasal 46

(1) Barang siapa menghimpun dana dari masyarakat dalam bentuk simpanan tanpa izin usaha dari pimpinan Bank Indonesia sebagaimana dimaksud dalam pasal 16, diancam dengan pidana penjara sekurang- kurangnya 5 tahun dan paling lama 15 tahun serta denda sekurang- kurangnya sepuluh milyar rupiah dan paling banyak dua ratus milyar rupiah.

(2) Dalam hal kegiatan sebagaimana dimaksud dalam ayat (1) dilakukan oleh badan hukum yang berbentuk perseroan terbatas, perserikatan, yayasan atau koperasi, maka penuntutan terhadap badan- badan dimaksud dilakukan baik terhadap mereka yang memberikan perintah melakukan perbuatan itu atau yang bertindak sebagai pimpinan dalam perbuatan itu atau terhadap kedua- duanya.

Ditelusuri dan ditelaah dari ketentuan yang tertuang dalam pasal 46 ayat (1) Undangundang Perbankan Nomor 10 Tahun 1998, mengatur perkataan "barang siapa" yang berarti orang- perorangan (individu) menghimpun dana dari masyarakat dalam bentuk simpanan tanpa memperoleh izin usaha dari pimpinan Bank Indonesia (sekarang Otoritas Jasa Keuangan) atau dikenal dengan istilah 'bank gelap', tidak menimbulkan persoalan dan dapat diterapkan ancaman pidana penjara minimal 5 tahun dan maksimal 15 tahun dan denda minimal sepuluh milyar rupiah dan mak-simal dua ratus milyar rupiah. Namun demikian, lain halnya apabila yang dilanggar ketentuan pasal 46 ayat (2) Undang- undang Perbankan Nomor 10 Tahun 1998, yang dilakukan oleh badan hukum yang berbentuk perseroan terbatas, perserikatan, ya-yasan atau koperasi, dikenal dengan istilah "korporasi”. Dalam pasal ini yang dike-nakan sanksi adalah ;

a. Yang memberi perintah melakukan perbuatan,

b. Yang bertindak sebagai pimpinan dalam perbuatan itu, dan

c. Kedua- duanya.

Pasal 46 ayat (2) Undang- undang Perbankan Nomor 10 Tahun 1998, tidak kon-sisten dalam mengatur masalah 'siapa yang dapat dituntut' dalam hal delik/ kejaha-tan dilakukan oleh korporasi. Korporasinya sendiri tidak dapat dituntut dan dipida-na. ${ }^{16}$ Dengan kata lain, dikenal adanya subjek hukum korporasi tetapi korporasinya sendiri tidak dapat dituntut dan diberikan sanksi. Pada hal potensi terjadinya kejaha-tan korporasi (corporate crime)

\footnotetext{
${ }^{16}$ Barda Nawawi Arief, 2010, Kapita Selekta Hukum Pidana, PT. Citra Aditya Bakti : Bandung, Halaman 149.
} 
peluangnya cukup besar di dunia perbankan, sebaik-nya pertanggungjawaban pidana korporasi dan sanksi pidananya perlu dirumuskan, dicantumkan dan ditegaskan dalam Undang- undang Perbankan. Hal ini perlu di-lakukan untuk meminilisir kerugian dan dalam rangka memberikan perlindungan terhadap masyarakat (nasabah) yang menjadi korban perbuatan/ tindak pidana perbankan yang dilakukan oleh korporasi.

Ditetapkannya korporasi sebagai subjek dan pelaku kejahatan (corporate crime), pada awalnya banyak menimbulkan pro dan kontra di kalangan ahli hukum pidana, dengan adanya doktrin dalam hukum pidana, yaitu universalitas delinquere no potest (korporasi tidak mungkin melakukan tindak pidana). Ini dipengaruhi oleh pemikiran, bahwa keberadaan 'korporasi' di dalam hukum pidana hanyalah fiksi hukum yang tidak mempunyai mind (kehendak), sehingga tidak mempunyai suatu nilai moral yang diisyaratkan untuk dapat dipersalahkan secara pidana (unsur kesalahan). Padahal dalam suatu delik/tindak pidana mensyaratkan adanya kesalahan (mens rea) selain adanya perbuatan (actus reus) atau dikenal dengan actus non facit reum,nisi mens sit rea.

Dalam menentukan pertanggung jawaban pidana korporasi (corporate crime) yang dilakukan perbankan dapat digunakan ajaran- ajaran doctrine of strict liability dan doctrine of vicarious liability. ${ }^{17}$ Berdasarkan ajaran strict liability pelaku tindak pidana dapat diminta pertanggung jawabannya tanpa diisyaratkan adanya kesalahan, sedangkan ajaran vicarious liability dimungkinkan adanya pembebanan pertanggung jawaban pidana dari tindak pidana yang dilakukan, dari si A kepada si B (per-tanggung jawaban pidana pengganti).

Sanksi yang dapat dikenakan atau diterapkan terhadap korporasi sebagai pelaku kejahatan (corporate crime) perbankan, pada dasarnya lebih berorientasi pada offender (baik berupa orang maupun korporasi). Sehingga belum terlihat orientasinya kepada korban (victim oriented), seperti pidana ganti rugi (restitusi/kompensasi). Untuk itu, perlu dipertimbangkan adanya pidana ganti rugi dan corporate probation untuk korporasi yang disertai syarat membayar ganti rugi terhadap korban. Corpo-rate probation identik dengan pidana bersyarat/ pengawasan (suspended sentence probation). Bentuk sanksi lainnya untuk korporasi yang berorientasi pada korban adalah sanksi publisitas (publicity sanction) dan pidana kerja sosial/pelayanan ma-syarakat (community service order). ${ }^{18}$

\footnotetext{
${ }^{17}$ Sutan Remy Sjahdeini, 2006, Pertanggungjawaban Pidana Korporasi, Grafiti Pers : Jakarta, Halaman 46.

${ }^{18}$ Barda Nawawi Arief, Op, Cit, Halaman 152.
} 
Korporasi sebagai subjek hukum dan dapat diminta pertanggung jawaban pi-dana serta dikenakan sanksi, pengaturan dan rumusannya sudah dicantumkan di dalam Undangundang lainnya, yaitu Undang- undang Pencegahan dan Pembe-rantasan Tindak Pidana Pencucian uang Nomor 25 Tahun 2003 yang diperbaharui dengan Undang- undang Nomor 8 Tahun 2010, Undang- undang Usaha Perasu-ransian Nomor 2 Tahun 1992, Undangundang Kepabean Nomor 10 Tahun 1995, Undang- undang Cukai 39 Tahun 2007, Undang- undang Psikotropika Nomor 5 Tahun 2007, Undang- undang Narkotika Nomor 22 Tahun 2007 dan Undang- undang Informasi dan Transaksi Elektronik Nomor 11 Tahun $2008 .^{19}$

Permasalahan lainnya terdapat juga dalam ketentuan pasal 47 Undang- undang Perbankan Nomor 10 Tahun 1998 yang berkaitan dengan rahasia bank.

\section{Pasal 47}

(3) Barang siapa tanpa membawa perintah tertulis atau izin dari pimpinan Bank Indonesia sebagaimana dimaksud dalam pasal 41,41A, 42 dengan sengaja memaksa bank atau pihak terafiliasi untuk memberikan keterangan sebagaimana dimaksud dalam pasal 40, diancam dengan pidana penjara sekurang-kurangnya 2 tahun dan paling lama 4 tahun serta denda sekurang-kurangnya sepuluh milyar rupiah dan paling banyak dua ratus milyar rupiah.

(4) Anggota dewan komisaris, direksi, pegawai bank atau pihak teralifiasi lainnya yang dengan sengaja memberikan keterangan yang wajib diraha-sikan menurut pasal 40, diancam dengan pidana penjara sekurang- kurangnya 2 tahun dan paling lama 4 tahun serta denda sekurang- kurangnya empat milyar rupiah dan paling banyak delapan milyar rupiah.

Dari substansi/materi yang dirumuskan pasal 47 Undang- undang Perbankan nomor 10 Tahun 1998 di atas, terlihat ada dua perbuatan/tindak pidana yang ber-kaitan dengan rahasia bank, yaitu ;

1) Orang yang berada di luar bank, orang- perorangan (individu) tanpa mem-bawa perintah tertulis atau izin dari pimpinan Bank Indonesia (sekarang Otoritas Jasa Keuangan) dengan memaksa bank dan pihak teralifiasi untuk memberikan keterangan rahasia keuangan nasabah penyimpan, diancam pidana penjara minimal

\footnotetext{
${ }^{19}$ Supanto, 2010, Kejahatan Ekonomi Global dan Kebijakan Hukum Pidana, Alumni : Bandung, Halaman 253.
} 
2 tahun dan maksimal 4 tahun dan denda minimal sepuluh milyar dan maksimal dua ratus milyar rupiah, dan

2) Orang yang berada di dalam bank, anggota dewan komisaris, direksi, pegawai bank atau pihak teralifiasi yang dengan sengaja memberikan/membocorkan rahasia keuangan nasabah penyimpan, dikenakan ancaman pidana penjara mi-nimal 2 tahun dan maksimal 4 tahun dan denda minimal empat milyar rupiah dan maksimal delapan milyar rupiah.

Substansi/materi yang diatur dalam pasal 47 Undang- undang Perbankan Nomor 10 Tahun 1998, apabila ditelusuri dan ditelaah terlihat masih belum optimal menga-tur persoalan rahasia bank dan masih terdapat kelemahan, ${ }^{20}$ yaitu ;

a) Kewajiban menjaga kerahasiaan keuangan nasabah penyimpan dana, bagai-mana jika nasabah penyimpan dana sudah berpindah tempat menyimpan dananya pada bank lain atau ditarik untuk keperluan lain, berapa jangka waktu untuk tetap merahasiakan keuangan nasabah penyimpan dana terse-but dalam pasal 47 ayat (2) Undang- undang Perbankan Nomor 10 Tahun 1998,

b) Kewajiban menjaga kerahasiaan keuangan nasabah penyimpan dana, khu-sus bagi karyawan bank pengertiannya yang cukup luas dan tidak realistis, ter-masuk karyawan bank yaitu satuan pengamanan (satpam), sopir (driver), pelayan (clening servis) yang tidak mempunyai hubungan penga-ruh dan akses dengan nasabah penyimpan dana, apakah kewajiban ini cukup realistis dibebankan pada mereka semestinya harus ada pengaturan secara spesifik, sebagaimana yang dirumuskan dalam pasal 47 ayat (2) Undang- undang Perbankan Nomor 10 Tahun 1998 ,

c) Bagaimana jika ada anggota dewan komisaris, direksi dan karyawan bank yang memasuki pensiun dan diberhentikan dengan tidak hormat (pemutusan hubungan kerja), masih adakah baginya kewajiban untuk menyimpan kerahasiaan keuangan nasabah penyimpan dana sebaiknya diberi ketentuan dan dibatasi,

d) Bagaimana sanksi pidana bagi penggunaan informasi rahasia bank yang ilegal, yang dilakukan oleh kalangan lembaga swadaya masyarakat, penggiat anti

${ }^{20}$ Sutan Remy Sjahdeini, Juni 2005, Makalah Rahasia Bank : Berbagai Masalah Disekitarnya, Disajikan Bahan Diskusi Legal Isues Seputar Pengaturan Rahasia Bank di Bank Indonesia. 
korupsi, yang menyuarakan dan membocorkan rahasia keuangan nasabah penyimpan dana yang belum diatur dan

e) Bagaimana sanksi pidana bagi pencurian informasi rahasia keuangan nasa-bah penyimpan dana yang didapat dan dibocorkan oleh penggunaan hackers yang juga belum dirumuskan dan diatur dalam Undang- undang perbankan.

Belum optimalnya pengaturan 'rahasia bank' sebagaimana yang dirumuskan dalam ketentuan pasal 47 Undang- undang Perbankan Nomor 10 Tahun 1998 seperti diuraikan di atas, sehingga pembahasan masalah rahasia bank tersebut mengalami pasang surut dan hasilnyapun kebanyakan masih pada tataran konseptual. Sekalipun mengenai rahasia bank dalam Undang- undang perbankan telah diatur, namun substansinya belum menyentuh titik keseimbangan antara berbagai kepentingan yang ada, sehingga format ideal tentang ketentuan rahasia bank yang diinginkan di Indonesia masih terus mencari bentuknya. ${ }^{21}$

Berbagai dilemma yang menyangkut rahasia bank, sudah saatnya disempur-nakan, karena masih belum dapat memecahkan masalah yang ada, bahkan menim-bulkan permasalahan yang harus segera dipecahkan. Untuk itu, sebaiknya ketentuan mengenai 'rahasia bank' diatur dalam Undang- undang tersendiri. Pengaturan ter-sendiri ini diperlukan untuk membuat pengaturan mengenai pengecualian ke-tentuan rahasia bank yang baku dan tidak bervariasi dan diatur di berbagai Undang- undang seperti saat ini.

Permasalahan lain yang terdapat dalam substansi/materi pasal 48 Undang- undang Perbankan Nomor 10 Tahun 1998, tindak pidana yang berkaitan dengan pengawasan dan pembinaan bank. Artinya, Bank Indonesia (sekarang Otoritas Jasa Keuangan) memiliki kewajiban melakukan pengawasan secara langsung dan tidak langsung atas kegiatan operasional bank serta memberikan pembinaan bagi bank, agar dalam menjalankan tugas patuh dan tunduk pada kode etik, menjaga integritas dan bertindak dengan prinsif penuh kehatian- hatian (prudential banking), mene-rapkan good corporate governance dan dengan menerapkan manajemen risiko serta mematuhi semua peraturan perundangundangan yang berlaku, yang tujuan akhirnya agar bank tetap terkendali dan terjaga dengan baik, likuiditas dan solvabilitasnya serta tetap sehat dan tangguh dalam menjalankan kegiatan operasionalnya.

Untuk itu, sesuai dengan ketentuan pasal 30 Undang- undang Perbankan Nomor 10 Tahun 1998, dalam rangka pengawasan dan pembinaan yang dilakukan oleh Bank

${ }^{21}$ Yunus Husein, 2010, Rahasia Bank dan Penegakan Hukum, Pustaka Juanda Tiga Lima : Jakarta, Halaman 1. 
Indonesia (sekarang Otoritas Jasa Keuangan), diwajibkan kepada anggota dewan komisaris, direksi atau pegawai bank, untuk menyampaikan kepada Bank Indonesia (sekarang Otoritas Jasa Keuangan), segala keterangan dan penjelasan mengenai usa-hanya dan memberikan kesempatan atas pemeriksaan buku- buku dan berkas- berkas yang ada padanya serta wajib memberikan bantuan yang diperlukan dalam rangka memperoleh kebenaran dari segala keterangan, dokumen dan penjelasan yang dila-porkannya. Selain itu, sesuai dengan ketentuan pasal 34 Undang- undang Perbankan Nomor 10 Tahun 1998, terhadap anggota dewan komisaris, direksi atau pegawai bank wajib menyampaikan neraca dan perhitungan laba/rugi tahunan serta penje-lasannya, serta laporan berkala lainnya dan waktu dan bentuk yang ditetapkan dan neraca serta perhitungan laba/rugi tahunan yang terlebih dahulu diaudit oleh akuntan publik. Kesemuanya ini dilakukan diarahkan dan ditujukan agar bank tetap terken-dali dan terjaga dengan baik tingkat kesehatannya, likuiditas dan solvabilitasnya dalam melayani dan melindungi kepentingan nasabahnya. Sehingga apabila terjadi hal- hal yang tidak diinginkan dan/ atau terjadi penyimpangan dengan tidak melaksanakan ketentuan pasal 30 dan pasal 34 Undangundang Perbankan Nomor 10 Tahun 1998 dalam menjalankan tugasnya, terhadap anggota dewan komisaris, direksi atau pegawai bank akan dikenakan ancaman pidana sebagaimana dirumuskan dalam ketentuan pasal 48 Undang- undang Perbankan Nomor 10 Tahun 1998.

Pasal 48

(3) Anggota dewan komisaris, direksi atau pegawai bank yang dengan sengaja tidak memberikan keterangan yang wajib dipenuhi sebagaimana dimaksud dalam pasal 30 ayat (1) dan ayat (2) dan pasal 34 ayat (1) dan ayat (2), diancam dengan pidana penjara sekurang- kurangnya 2 tahun dan paling lama 10 tahun serta denda sekurang- kurangnya lima milyar rupiah dan paling banyak seratus milyar rupiah.

(4) Anggota dewan komisaris, direksi atau pegawai bank yang lalai membe-rikan keterangan yang wajib dipenuhi sebagaimana dimaksud dalam pasal 30 ayat (1) dan ayat (2) dan pasal 34 ayat (1) dan ayat (2), diancam dengan pidana kurungan sekurang- kurangnya 1 tahun dan paling lama 2 tahun dan atau denda sekurangkurangnya satu milyar rupiah dan paling banyak dua milyar rupiah.

Dalam ketentuan pasal 48 Undang- undang Perbankan Nomor 10 Tahun 1998, diatur dan dirumuskan ketentuan kewajiban bagi anggota dewan komisaris, direksi atau pegawai 
bank menyampaikan segala keterangan dan penjelasan mengenai usahanya, kebenaran data/berkas- berkas laporannya dan menyampaikan neraca dan perhitungan laba/rugi tahunan yang telah diaudit oleh akuntan publik. Tetapi ada beberapa hal yang prinsif dan krusial yang belum diatur dalam pasal 48 dan pasal 49 Undang- undang perbankan ini, yang menyangkut, ${ }^{22}$ yaitu ;

(1) Kejahatan yang menyangkut pemberian informasi yang tidak benar dan menyesatkan kepada masyarakat (nasabah),

(2) Kejahatan yang menyangkut praktik bank dalam bank,

(3) Yang menyangkut pelanggaran ketentuan batas maksimum pemberian kre-dit,

(4) Perbuatan- perbuatan yang mengandung unsur tindak pidana korupsi, dan

(5) Pertanggung jawaban korporasi bank sebagai pelaku kejahatan dalam rang-ka memberikan perlindungan terhadap nasabah.

Tindakan/perbuatan pejabat atau pegawai bank yang memberian informasi yang tidak benar dan menyesatkan ini, perlu dirumuskan dan/ atau diformulasikan dalam Undangundang perbankan. Sehingga dapat dicegah dan ditanggulangi terjadinya perbuatan/tindakan pejabat atau pegawai bank yang dapat menimbulkan korban dan kerugian bagi masyarakat. Bank Indonesia (sekarang Otoritas Jasa Keuangan), perlu secara terus- menerus meningkatkan kegiatan edukasi kepada masyarakat secara terstruktur, terencana dan terkordinasi dengan memberikan pengetahuan dan me-ningkatkan pemahaman serta prinsif kehati- hatian atas segala risiko tugas dan fungsi bank serta semua layanan produk dan jasa bank.

Diharapkan juga tingkat kewaspadaan/kehati- hatian dari masyarakat jangan cepat terpancing dan percaya begitu saja dengan janji/hadiah, bonus dan bunga yang cukup tinggi yang tidak layak diberikan, tentu ada motif/modus tertentu yang pada akhirnya bermuara pada penyalahgunaan dengan menggelapkan dana masyarakat, untuk kepentingan kelompok atau pribadinya.

Kejahatan yang menyangkut praktik bank dalam bank merupakan usaha bank dalam bank tanpa izin yang berlindung pada usaha bank yang resmi, ${ }^{23}$ yaitu mela-kukan kegiatan usaha yang dilarang menggunakan dana masyarakat (nasabah) tanpa seizin Bank Indonesia

${ }^{22}$ M. Arief Amrullah, 2002, Politik Hukum Pidana Dalam Perlindungan Korban Kejahatan Ekonomi di Bidang Perbankan, Jurnal Hukum Fak. Hukum UII No. 21 Volume 9 : Jogyakarta, Halaman 17.

${ }^{23}$ Muhammad Djumhana, Op, Cit, Halaman 463. 
(sekarang Otoritas Jasa Keuangan). Artinya, dana masyarakat yang disimpan pada bank digunakan untuk tujuan- tujuan tertentu memperkaya diri pribadi atau kelompok/groupnya, diselewengkan baik dananya dipakai untuk berpoya- poya keperluan pribadi maupun dalam bentuk pemberian kredit terhadap kelompok/groupnya tanpa kelayakan agunan dan bunga yang seimbang dan tidak diproses secara ketat serta selektip, tanpa memperhatikan kelayakan usahanya dan tidak mengikuti prosedur pemberian kredit yang ditetapkan bank dalam Standar Operational Procedur (SOP) yang sebenarnya. Pada akhirnya, akibat tidak dilakukan analisis secara benar dan baik, sehingga terjadi pembengkakan kredit macet yang tidak bisa ditutupi di atas kewajaran yang berisiko bank pada akhirnya dapat terkena likuidasi.

Kejahatan praktik bank dalam bank berbeda gradasinya dengan pendirian bank tanpa izin dari pimpinan Bank Indonesia (sekarang Otoritas Jasa Keuangan) seba-gaimana yang dituangkan dalam ketentuan pasal 46 ayat (2) Undang- undang perbankan Nomor 7 Tahun 1992 yang diperbaharui dengan Undang- undang Nomor 10 Tahun 1998. Apabila kejahatan praktik bank dalam bank, banknya sudah mendapat izin resmi dari pimpinan Bank Indonesia, tetapi dalam praktik bank itu secara internal menjalankan usaha bank dengan menarik/menggunakan dana masya-rakat untuk diselewengkan/disalahgunakan untuk kepentingan memperkaya diri pribadi dan kelompok/groupnnya. Dengan modus memberikan kredit ke kelom-pok/groupnya bukan disalurkan pada masyarakat yang membutuhkan, dan dalam pemberian kredit tidak mengikuti ketentuan yang ditetapkan bank, tanpa agunan yang jelas dan bunga yang sebanding.

Praktik bank yang tidak memiliki izin dari pimpinan Bank Indonesia, yaitu sejak dari semula awal memang keberadaan bank itu tidak memiliki izin atau disebut dengan 'bank gelap', dalam menghimpun/menarik dana masyarakat dalam bentuk tabungan, deposito dan lainnya. Sehingga kegiatannya yang menjalankan usaha serupa bank dalam bentuk badan hukum tersebut tanpa izin dapat dikenakan ancaman pasal 46 ayat (2) Undangundang Perbankan Nomor 7 Tahun 1992 yang diperbaharui dengan Undang- undang Nomor 10 Tahun 1998. mengingat belum diatur dan dirumuskan kejahatan dalam bentuk praktik bank dalam bank dalam Undang- undang perbankan, sebaiknya perbuatan/tindakan ini menjadi perhatian untuk diformulasikan dalam Undang- undang perbankan. Dengan tujuannya, tiada lain untuk mengurangi terjadinya kejahatan praktik bank dalam bank yang terjadi selama ini, yang dapat menimbulkan korban pada masyarakat dan kerugian. 
Pengertian Batas Maksimum Pemberian Kredit (BMPK) dimaksudkan untuk mengatur portopolio kredit perbankan agar tidak terakumulasi pada satu kelompok atau individual dalam memberikan kredit, sebab konsentrasi kredit pada kelompok atau individu tertentu akan mengandung risiko sangat besar bagi bank. ${ }^{24}$ Bank Indonesia menentukan bahwa pemberian kredit kepada nasabah harus dibedakan antara pihak terkait dengan bank dan pihak yang tidak terkait dengan bank. Pihak terkait dengan bank adalah peminjam dan/atau kelompok peminjam yang mempu-nyai keterkaitan dengan bank, seperti dewan komisaris, direksi, pegawai bank beserta keluarganya.

Berdasarkan Peraturan Bank Indonesia Nomor 7/2005 jo Peraturan Bank Indonesia Nomor 8/2005, batas maksimum pemberian kredit ditentukan yaitu :

(a) Pemberian kredit oleh bank kepada pihak terkait dengan bank ditetapkan pa-ling tinggi $10 \%$ dari modal bank,

(b) Pemberian kredit oleh bank kepada yang bukan merupakan pihak terkait dengan bank ditetapkan paling tinggi $20 \%$ dari modal bank, dan

(c) Pemberian kredit oleh bank kepada kelompok peminjam yang bukan meru-pakan pihak terkait dengan bank ditetapkan paling tinggi $25 \%$ dari modal bank.

Bank memberikan kredit pada peminjam yang melebihi batas yang ditetapkan oleh Bank Indonesia, untuk pihak terkait dengan bank di atas 10\% dari modal bank dan bukan pihak terkait dengan bank di atas $20 \%$ dan pada kelompok yang bukan pihak terkait di atas 25\% dari modal bank, berarti bank telah melakukan pelanggaran batas maksimum pemberian kredit. Jika pelanggaran batas maksimum pemberian kredit yang jumlahnya cukup kecil, karena ada unsur kelalaian dapat dikatagorikan pelanggaran administratif saja.

Batas maksimum yang diberikan dalam jumlah dana yang lebih besar prosen-tasenya, dilakukan karena ada unsur kesengajaan dengan tidak mengikuti peraturan yang berlaku ditetapkan oleh Bank Indonesia. Perbuatan/ tindakan pejabat bank ini dapat dikatagorikan suatu bentuk kejahatan yang membahayakan bank dan sekaligus membahayakan dana masyarakat yang dititipkan padanya, sehingga perlu diatur dan dirumuskan dalam Undangundang perbankan.

Perbuatan- perbuatan yang mengandung unsur pidana korupsi, dimaksudkan bahwa dalam tindak pidana perbankan memiliki keterkaitan dengan unsur- unsur tindak pidana korupsi yang diatur dalam Undang- undang Pemberantasan Tindak Pidana Korupsi Nomor

\footnotetext{
${ }^{24}$ Batas Maksimum Pemberian Kredit (BMPK), staff.uny.ac.id, Halaman 4.
} 
31 Tahun 1999 yang diperbaharui dengan Undang- undang Nomor 20 Tahun 2001 dan sebagaimana yang juga diatur dan dirumuskan dalam ketentuan pasal 49 Undang- undang Perbankan Nomor 7 Tahun 1992 yang diper-baharui dengan Undang- undang Nomor 10 Tahun 1998. Jelasnya, ada dua Undang- undang yang mengatur unsur- unsur tindak pidana korupsi baik di Undang- undang pemberantasan tindak pidana korupsi dan Undangundang perbankan itu sendiri. Agar tidak timbul kerancuan dalam implementasinya sebaiknya ketentuan ini ditegaskan dalam Undang- undang perbankan, dan dengan menerapkan Undang- undang perbankan dan bukan undang- undang pemberantasan tindak pidana korupsi yang selama ini banyak menjerat pejabat bank yang melakukan tindak pidana korupsi.

Penerapan azas kekhususan sistematis dalam pasal 14 Undang- undang Pem-berantasan Tindak Pidana Korupsi Nomor 31 Tahun 1999 yang diperbaharui dengan Undang- undang Nomor 20 Tahun 2001, yang merupakan pengembangan dari azas lex spesialis derogate legi generali yang terdapat di dalam pasal 63 ayat (2) KUHP, di mana diberlakukan penerapan Undang- undang yang "lebih khusus dari yang khusus" dalam proses penegakan hukum dan dengan tidak dicantumkan azas kekhu-susan sistematik hukum pidana administrasi dalam Undang- undang Perbankan Nomor 7 Tahun 1992 yang diperbaharui dengan Undang- undang Nomor 10 Tahun 1998, sehingga rumusan yang termuat di dalam Undang- undang perbankan menjadi wilayah abu- abu (gray area) dan dapat menimbulkan multi interprestasi.

Melihat azas kekhususan sistematis ini belum lengkap karena hanya ada pada Undang- undang tindak pidana korupsi, sementara dalam Undang- undang pidana administrasi yang mempunyai sanksi pidana di bidang perbankan, tidak ada penje-lasan secara spesifik. Sebaiknya, harus adanya penormaan azas kekhususan siste-matis di dalam Undang- undang pidana administrasi di bidang perbankan. Perlunya diformulasikan dan atau dirumuskan penormaan secara eksplisit azas kekhususan sistematis ke dalam Undang- undang pidana administrasi di bidang perbankan. Ditujukan untuk mengatasi terjadinya kriminalisasi kebijakan yang disebabkan adanya perdebatan panjang antara hukum pidana korupsi dan hukum pidana admi-nistrasi di bidang perbankan. Ada limitasi yang jelas antara pidana administrasi di bidang perbankan dan pidana korupsi, yang tujuannya agar bisa tercapai pem-bentukan hukum dan upaya penegakan hukum yang efisien dan epektif di bidang perbankan. 
Permasalahan lain dari substansi/materi yang termuat di dalam Undang- undang Perbankan Nomor 7 Tahun 1992 yang diperbaharui dengan Undang- undang Nomor 10 Tahun 1998, adalah belum diaturnya secara rinci dan terstruktur persoalan per-lindungan terhadap nasabah bank. Padahal persoalan perlindungan terhadap nasabah yang menjadi korban tindak pidana perbankan kian menjadi penting dan perlu untuk diperhatikan, mengingat kerugian dan akibat yang ditimbulkan cukup besar, se-hingga pengaturan perlindungan korban (nasabah bank) perlu diakomodir di dalam Undang- undang perbankan.

Persoalan perlindungan terhadap nasabah dalam sistem perbankan di Indonesia masih belum terlembaga dengan baik, sehingga penegakan dan penerapan hukum pidananya kian menjadi lemah dan belum optimal. Padahal sudah ada pengaturan perlindungan terhadap saksi dan korban dalam Undang- undang Nomor 13 Tahun 2006, yang dalam pasal 1 ayat (2) nya disebutkan 'korban adalah seseorang yang mengalami penderitaan phisik, mental dan/atau kerugian ekonomi'. Dengan demiki-an, perlindungan korban diakomodir dan diakui yang berkaitan dengan kerugian ekonomi termasuk korban tindak pidana di bidang perbankan dalam Undang- undang tersebut.

Begitu juga di dalam ketentuan pasal 7 hurup f Undang- undang Perlindungan Konsumen Nomor 8 Tahun 1999, yang memberikan 'kompensasi, ganti kerugian dan/atau penggantian atas kerugian akibat penggunaan, pemakaian dan pemanfaatan barang dan/atau jasa yang diperdagangkan'. Artinya, terhadap konsumen (nasabah bank) yang menderita kerugian akibat perbuatan yang dilakukan secara tidak ber-tanggung jawab dan melawan hukum, berhak atas kompensasi dan atau ganti kerugian. Walaupun sudah ada ketentuan Undang- undang Perlindungan Konsumen Nomor 8 Tahun 1999, tetapi dalam beberapa kasus konsumen (nasabah bank) yang menjadi korban tindak pidana perbankan tidak mendapat perlindungan hukum secara optimal. ${ }^{25}$

Di dalam Undang- undang perbankan belum ada pengaturannya secara integratif dan komprehensif, sehingga di dalam substansi/materi Undang- undang perbankan perlu dirumuskan dan diformulasikan ketentuan tentang perlindungan terhadap korban (nasabah bank) secara jelas dan terperinci dengan mengkriminalisasikan, mulai dari rumusan perbuatan/tindak pidana, pertanggung jawaban pidana beserta pidana dan pemidanaan. Terhadap korporasi dapat dijerat dan dijadikan sebagai subjek dan pelaku tindak pidana

${ }^{25}$ Yusuf Shofie, 2009, Perlindungan Konsumen dan Instrument- instrument Hukumnya, PT. Citra Aditya Bakti : Bandung, Halaman 81. 
perbankan. Dengan ditetapkan korporasi dapat dijadikan sebagai subjek dan pelaku kejahatan/tindak pidana perbankan, sehingga dapat memberikan perlindungan terhadap nasabah yang menjadi korban bukan hanya terhadap calon korban (potential victim) melainkan juga perlindungan terhadap korban secara langsung (actual victim), sehingga akan menciptakan keseimbangan dalam hukum pidana antara pelaku dengan korban dan antara calon korban dengan korban secara langsung. Pengenaan sanksi pidana denda yang cukup tinggi terhadap korporasi (bank) dengan kombinasi alternatip sanksi pidana lainnya, seperti publicity sanction. ${ }^{26}$

Kelemahan lain dari substansi/materi yang termuat dalam Undang- undang perbankan,tidak diatur mengenai beban tanggungjawab bagi sipembuat/pelaku per-cobaan, pembantuan dan pembuat/pelaku permufakatan jahat untuk melakukan tindak pidana perbankan, padahal katagori yang disebutkan dimaksud diatur dalam pasal 15 Undangundang pemberantasan tindak pidana korupsi. Termasuk juga perbuatan menyalahgunakan kewenangan karena jabatan atau kedudukan, menya-lahgunakan sarana karena jabatan atau kedudukan, subjek tindak pidana diperluas, sanksi pidana baik pidana pokok maupun pidana tambahan diatur sedemikian rupa. ${ }^{27} \mathrm{Hal}$ ini dilakukan untuk mengantisipasi dalam upaya penanggulangan tindak pidana perbankan yang perkembangannya semakin kompleks ke depannya.

Ditelusuri dan ditelaah dari substansi Undang- undang Perbankan Nomor 7 Tahun 1992 yang diperbaharui dengan Undang- undang nomor 10 Tahun 1998, da-lam hal masalah jenis dan perumusan sanksi pidana/sanksi administratif, hanya mencantumkan pidana pokok berupa penjara/kurungan dan denda yang dirumuskan secara kumulatif. Jelasnya, tidak ada pidana tambahan atau jenis sanksi tindakan yang diintegrasikan ke dalam sistem pemidanaan.

Perumusan pidana pokok dan denda secara kumulatif, mengandung kelemahan dan dikhawatirkan tidak epektif, ${ }^{28}$ yang disebabkan ;

1. Perumusan sanksi pidana yang bersifat kumulatif yang imperatif sehingga sangat kaku untuk diterapkan, mengingat hakim tidak diberi kesempatan untuk memilih sanksi pidana yang dijatuhkan,

2. Kumulasi pidana penjara dan denda sulit diterapkan untuk korporasi, dan

\footnotetext{
${ }^{26} \mathrm{M}$. Arief Amrullah, op, Cit, Halaman 21.

${ }^{27}$ Hartiwiningsih, $O p$, Cit, Halaman 25.

${ }^{28}$ Barda Nawawi Arief, Op, Cit, Halaman 154.
} 
3. Dengan dikumulasikannya pidana denda yang tinggi (minimal satu milyar rupiah dan maksimal dua ratus milyar rupiah) dengan pidana penjara/ku-rungan, dikhawatirkan denda tidak akan dibayar karena dalam Undang- undang perbankan tidak ada ketentuan khusus yang menyimpang dari pasal 30 KUHP (apabila tidak dibayar, hanya dikenakan pidana kurungan pengganti 6 bulan atau maksimal 8 bulan apabila ada pemberatan).

Dalam upaya mengantisipasi kelemahan perumusan pidana pokok dan denda secara kumulasi, sebaiknya dibuat kebijakan formulasi dalam Undang- undang per-bankan, ${ }^{29}$ sebagai berikut ;

a. Menggunakan perumusan kumulatif alternatif,

b. Dibuat aturan khusus yang menyimpang dari pasal 30 KUHP dengan menga-cu perumusan seperti pasal 16 Undang- undang Nomor 31 Tahun 1999 (mengenai pelaksanaan uang pengganti) atau seperti pasal 76 konsep RUU KUHP Tahun 2000, yaitu jika denda tidak dibayar, harta bendanya disita dan dilelang untuk membayar denda itu atau diambil dari pendapatan terpidana dan tidak tidak ada (tidak cukup), dikenakan pidana penjara dan/atau ku-rungan pengganti yang lamanya tidak melebihi maksimum pidana penjara dan/atau kurungan yang diancamkan, dan

c. Dibuat aturan khusus yang menyimpang dari pasal 30 KUHP untuk denda yang tidak dibayar oleh korporasi, aturan seperti sub b di atas, tetapi dengan pidana pengganti yang sesuai untuk korporasi (misalnya pencabutan izin usaha, pembekuan kegiatan usahanya ataupun pembubaran korporasi yang diikuti dengan likuidasi.

Permasalahan lain walaupun ada sanksi administratif dalam Undang- undang perbankan, akan tetapi tidak diintegrasikan ke dalam sistem pemidanaan, walaupun ada di antaranya yang dapat dikatagorikan sebagai pidana tambahan atau tinda-kan. ${ }^{30}$ Dengan tidak diintegrasikan sanksi administratif ke dalam sistem pemi-danaan, memberikan kesan kuat bahwa pembuat Undang- undang masih membe-dakan antara sanksi pidana dan sanksi administratif. Padahal sebenarnya bisa saja sanksi administratif itu dioperasionalkan/ difungsikan melalui hukum pidana se-hingga dikenal dengan istilah hukum pidana administratif. Jadi, pada hakikatnya hukum pidana administratif merupakan perwujudan

${ }^{29} \mathrm{Ibid}$, Halaman 155.

${ }^{30} \mathrm{Ibid}$, Halaman 150 
dari kebijakan menggunakan hukum pidana sebagai sarana untuk menegakkan/melaksanakan hukum admi-nistrasi. ${ }^{31}$

\section{Dilihat Dari aspek Struktur/Kelembagaan Aparat Penegak Hukum}

Penerapan pidana merupakan bagian dari menegakkan kaidah/norma sanksi pidana yang tertuang di dalam pasal 46 hingga sampai pasal 50A Undang- undang Perbankan Nomor 7 Tahun 1992 yang diperbaharui dengan Undang- undang Nomor 10 Tahun 1998 dan di luar Undang- undang Perbankan terhadap pelaku tindak pidana yang berkaitan dengan kegiatan operasional perbankan. Penerapan pidana merupakan tugas dan tanggung jawab aparat penegak hukum (penyidik, penuntut umum, hakim pengadilan, penasehat hukum dan lembaga pemasyarakatan), yang dalam praktiknya penegakan hukum dalam menerapkan pidana tidaklah semudah yang dibayangkan apabila dibandingkan dengan tindak pidana biasa yang dilakukan secara konvensional, seperti tindak pidana pencurian, penipuan, penggelapan, pe-malsuan dan lainnya. Mengingat tindak pidana perbankan merupakan bagian dan salah satu bentuk dari tindak pidana di bidang ekonomi, tindak pidana di bidang ekonomi ini sering disebut dengan kejahatan kerah putih (white collar crime) ${ }^{32}$

Tindak pidana perbankan merupakan salah satu bentuk dari tindak pidana di bidang ekonomi, karena kehidupan perbankan merupakan urat nadi kehidupan eko-nomi, dengan demikian dalam membicarakan pelanggaran pada dunia perbankan tidak bisa terlepas dari pembicaraan tindak pidana di bidang ekonomi, yang secara umum tindak pidana di bidang ekonomi adalah tindakan melanggar hukum yang dilakukan dengan motif- motif ekonomi. ${ }^{33}$ Tindak pidana di bidang perbankan seba-gai bagian dan bentuk dari tindak pidana ekonomi biasanya dilakukan dengan prose-dur dan cara yang sangat rumit, sehingga dikatagorikan sebagai kejahatan kerah putih atau white collar crime, yang dapat dibedakan, ${ }^{34}$ yaitu ;

a. Kejahatan yang dilakukan oleh kalangan profesi dalam melakukan peker-jaannya, seperti advokat/pengacara, akuntan dan dokter,

b. Kejahatan yang dilakukan oleh pemerintah atau aparatnya, seperti korupsi dan tindakan penyalahgunaan kekuasaan, pelanggaran terhadap hak warga negara, dan

\footnotetext{
${ }^{31} \mathrm{Ibid}$, Halaman 151.

${ }^{32}$ Hermansyah, Op, Cit, Halaman 147.

${ }^{33}$ Muhammad Djumhana, Op, Cit, Halaman 451.

${ }^{34}$ Ibid, Halaman 580.
} 
c. Kejahatan korporasi.

Ciri- ciri khas yang terdapat dalam kejahatan kerah putih atau white collar crime adalah bahwa kejahatan tersebut dilakukan si pelaku dengan jalan menyalahgunakan kepercayaan yang diberikan kepadanya dari perusahaan atau masyarakat, ${ }^{35}$ Oleh karenanya kejahatan white collar crime sering terjadi pada lembaga- lembaga tempat masyarakat menaruh kepercayaan, seperti bank dan lainnya. Tindak pidana perban-kan yang merupakan salah satu bentuk kejahatan kerah putih atau white collar crime memiliki ciriciri tersendiri dari kejahatan lainnya, ${ }^{36}$ yaitu ;

1) Pelaku mempunyai tingkat kemampuan dan tingkat intelektual yang cukup tinggi dan bahkan melebihi tingkat kemampan dari aparat penegak hukum, sehingga sulit mengungkapkannya,

2) Pelaku memiliki sarana dan prasarana yang lebih canggih dari sarana dan prasarana yang dimiliki aparat penegak hukum, dan

3) Pelaku mengetahui celah- celah atau kelemahan dari Undang- undang atau peraturan yang berlaku yang berkaitan dengan kegiatan atau dengan bidang tujuannya dan memiliki kelebihan untuk memanfaatkan kelemahan dari Un-dangundang atau peraturan tersebut.

Tindak pidana di bidang perbankan yang merupakan salah satu bentuk dari kejahatan kerah putih atau white collar crime, yang dalam praktiknya kejahatan ini sulit dilacak (untuaceable crime), tidak ada bukti tertulis (paperless crime), tidak kasat mata (disdiscernible crime) dan dilakukan dengan cara yang rumit (inticrate crimes). ${ }^{37}$ Dengan menelusuri dan menelaah tindak pidana di bidang perbankan yang merupakan bagian dan salah satu bentuk kejahatan kerah putih (white collar crime) dengan ciri- ciri khas seperti di atas, jelas hal ini merupakan faktor yang dapat menghambat dalam upaya penanggulangan tindak pidana di bidang perbankan.

Faktor penghambat lainnya, tindak pidana di bidang perbankan yang terjadi dalam praktik sering menggunakan modus operandi dengan menggunakan tehnologi informasi yang cukup canggih, yang dilakukan melalui dunia maya (cyber crime), seperti dengan

${ }^{35}$ Ibid, Halaman 582.

${ }^{36}$ Yunan Sawidji, 1996, Kebijakan Penal Indonesia Terhadap Kejahatan Teroganisir, Fak. Hukum UGM : Jogyakarta, Halaman 9.

${ }^{37}$ Yenti Garnasih, Mei 2015,Materi Seminar 'Optimalisasi Penelusuran Hasil Tindak Pidana Perbankan' yang diselenggarakan LPS dan Jurnalis Indonesia, Jakarta, Halaman 1. 
cara skimming, yaitu dengan melakukan tindak pidana pencurian data- data nasabah menggunakan alat perekam data, biasanya dilakukan di mesin anjungan tunai mandiri, menggunakan phising, yaitu suatu upaya penipuan yang dicirikan dengan percobaan mendapatkan informasi seperti kata sandi dan kartu kre-dit. Biasanya ini dilakukan seseorang dengan menyamar sebagai pebisnis yang terpercaya untuk sebuah komunikasi elektronik resmi dan dilakukan dengan cara software atau malware pada jaringan internet. Malware merupakan virus yang dapat menyebar secara langsung ke layar monitor yang sedang mengakses jaringan internet, biasanya dilakukan kepada para nasabah yang melakukan transaksi melalui e-banking.

Dilihat dari aspek struktur/kelembagaan aparat penegak hukum yang merupakan bagian dari sistem hukum yang digagas oleh Lawrence M. Friedman di dalam upaya penanggulangan tindak pidana di bidang perbankan, ditelaah dalam penerapan pi-dana terhadap pelaku kejahatan perbankan merupakan kejahatan ekonomi dan terma-suk dalam bentuk kejahatan kerah putih (white collar crime) dengan ciri sulit dilacak, tidak ada bukti tertulis, dilakukan secara kasat mata, dengan cara yang rumit/tidak terdeteksi, dilakukan para intelektual dan menggunakan sarana dan prasarana dengan modus yang cukup canggih melalui dunia maya/cyber crime (skimming, phising dan software dan/atau malware), sehingga hambatan lainnya untuk epektivitas penega-kan dan penerapan pidana sangat tergantung dari segi kemampuan aparat penegak hukumnya.

Dilihat dari segi kemampuan aparat penegak hukum dalam membangun kerja-sama dalam penegakan dan penerapan pidana dalam upaya upaya penanggulangan tindak pidana di bidang perbankan dalam kenyataan praktiknya, terlihat masih belum optimalnya koordinasi yang dilakukan, sehingga dapat menyebabkan tejadinya tum-pang tindih (overloping) dalam proses penyelidikan, penyidikan dan penuntutan yang dilakukan antar penegak hukum itu sendiri. Terjadinya tumpang tindih karena Un-dang- undang memberikan celah untuk itu, di mana dalam proses penyelidikan dan penyidikan terhadap kasus- kasus tindak pidana di bidang perbankan, selain proses penyelidikan dan penyidikan dapat dilakukan penyidik kepolisian (pasal 6 ayat (1) a KUHAP dan pasal 14 ayat (1) a Undang- undang Kepolisian Republik Indonesia Nomor 2 Tahun 2002) juga dapat dilakukan oleh penyidik Otoritas Jasa Keuangan (pasal 49 Undang- undang Otoritas Jasa Keuangan Nomor 21 Tahun 2011), penyidik kejaksaan (pasal 30 ayat (1) d Undangundang Kejaksaan Republik Indonesia Nomor 16 Tahun 2004) dan penyidik Komisi 
Pemberantasan Korupsi (pasal 6 c Undang- undang Komisi Pemberantasan Korupsi Nomor 30 Tahun 2002).

Adanya kewenangan penyelidikan dan penyidikan tindak pidana di bidang per-bankan tidak berada dalam satu garis komando, dan tersebar di beberapa aparat penegak hukum sehingga hal ini dapat mengurangi epektivitas dalam penegakan dan penerapan pidana dalam upaya penanggulangan tindak pidana perbankan secara cepat dan tepat dalam rangka memberikan perlindungan terhadap masyarakat. Hal ini jelas tidak sejalan dan selaras dengan semangat integrated criminal justice system, yaitu adanya suatu keterpaduan dalam proses sistem peradilan, ${ }^{38}$ baik dalam hal kordinasi maupun supervisi antar penyidik. Kenyataan ini tak dapat dipungkiri dari penanganan kasus Bank Century yang sudah dilakukan penyelidikan dan penyidikan oleh penyidik kepolisian, kejaksaan dan Komisi Pemberantasan Korupsi yang hingga saat ini belum mampu mengakomodir dan memberikan proses penyelesaian secara berkeadilan dan memiliki kepastian hukum secara cepat dan tuntas sebagaimana yang diharapkan masyarakat.

Faktor kelemahan selain dalam kordinasi antar aparat penegak hukum, untuk menentukan berhasil tidaknya dalam penegakan dan penerapan pidana dalam upaya penanggulangan tindak pidana di bidang perbankan sangat tergantung dan ditentukan kemampuan aparat penegak hukum yang dapat dilihat dari beberapa sisi, baik dilihat kualitas (memiliki keahlian, ketrampilan dan pengalaman) maupun segi kuantitas (jumlah personil/sumber daya manusia) yang tersedia. Apalagi menghadapi pelaku tindak pidana di bidang perbankan yang dilakukan dengan modus cukup canggih dan modern yang berbasis tehnologi informasi.

Dalam praktik meskipun tindak pidana perbankan jumlahnya cukup banyak, bahkan ada kecenderungan terus berkembang dan meningkat. Namun tidak banyak dari jumlah tersebut yang dilakukan penegakan dan penerapan hukum pidananya, ${ }^{39}$ mengingat karakteristik dari tindak pidana perbankan itu sendiri yang berbeda dengan tindak pidana lainnya, yaitu pelaku memiliki pemahaman yang cukup baik atas seluk beluk industri perbankan, memiliki keahlian di bidang tertentu, mengana-lisis, manajemen skill dan

\footnotetext{
${ }^{38}$ Barda Nawawi Arief, Op, Cit, Halaman 61.

${ }^{39}$ Supaijo, Januari 2010, Penegakan Hukum Pidana Dalam Kejahatan Perbankan,
} Artikel Ilmiah E Journal IAIN Raden Intan, Halaman 93. 
lainnya, memiliki privacy atau jabatan, agresif serta ambisius. ${ }^{40}$ Sehingga aparat penegak hukum menemui kesulitan dalam penegakan dan penerapan pidananya.

Keterbatasan kemampuan/keahlian (skill) aparat penegak hukum dan lemahnya dalam penguasaan tehnologi canggih, dibarengi pula dengan modus kepiawaian pelaku dalam menggunakan kecanggihan tehnologi informasi melalui cyber crime (skimming, phising dan software/malware) yang tidak meninggalkan jejak, sulit dideteksi, tidak diketahui tempus delicti (waktu kejadian) dan locos delicti (tempat kejadian)yang menjadi prasyarat dalam penyidikan dan penuntutan. Hal ini tentu dapat menyulitkan dan sekaligus menjadi faktor penghambat yang mengakibatkan berlarut- larutnya dalam proses penyelesaian dan upaya penanggulangan tindak pidana di bidang perbankan.

Dalam upaya menegakan dan menerapkan pidana terhadap pelaku tindak pidana di bidang perbankan yang lebih penting lagi diprioritaskan adalah ketersediaan tenaga/sumber daya aparat penegak hukum yang berkualiatas (keahlian/skill, ketram-pilan dan pengalamannya), khususnya pengetahuan teknis dalam hal penguasaan dan penggunaan informasi tehnologi, seperti komputer, internet banking, data- data digital dan lainnya. Perlu diperhitungkan pula jumlah sumber daya yang tersedia yang terus ditingkatkan, menghadapi tindak pidana perbankan yang tidak mengenal waktu dan tempat berlakunya antar daerah, wilayah dan bahkan antar negara.

Ditingkatkan kerjasama secara sinergis yang harus dibangun dan diberdayakan secara berkelanjutan antara aparat penegak hukum yang satu dengan aparat penegak hukum yang lainnya (kepolisian, kejaksaan, hakim pengadilan, lembaga pema-syarakatan dan advocat/penasehat hukum), untuk mempercepat dan memperlancar dalam upaya penanggulangan tindak pidana di bidang perbankan. Kerja sama yang dibangun dimaksud, bukan saja terbatas antar sesama aparat penegak hukum saja melainkan meliputi kerja sama dengan Bank Indonesia selaku otoritas yang ber-wenang melakukan pembinaan terhadap lembaga perbankan. Kerja sama ini dimak-sudkan untuk memberikan informasi terhadap aparat penegak hukum dalam mengan-tisipasi dan mengambil langkah- langkah yang diperlukan guna mencegah dan menanggulangi terjadinya tindak pidana di bidang perbankan.

Kerja sama antara aparat penegak hukum dengan Otoritas Jasa Keuangan (OJK) sebagai lembaga yang memiliki otoritas melakukan pengawasan dan penindakan/

${ }^{40}$ M. Sholehuddin, 2003, Sistem Sanksi Dalam Hukum Pidana : Ide Dasar Doble Track Sistem dan Implementasinya, PT. RajaGrafindo Persada : Jakarta, Halaman 17. 
penyelidikan dan penyidikan, yang perlu dilakukan sinkronisasi dan harmonisasi antara aparat penegak hukum dengan Otoritas Jasa keuangan, apabila terjadi suatu tindak pidana di bidang perbankan. Dengan dilakukan kerja sama secara sinergis dan terkoordinasi dengan baik, diharapkan dapat mempercepat proses penyelesaian tin-dak pidana di bidang perbankan tersebut. Begitu pula kerja sama antara aparat pene-gak hukum dengan otoritas Pusat pelaporan dan Analisis Transaksi Keuangan (PPATK). Kerja sama ini penting artinya terhadap adanya kejahatan pencucian uang (money loundering) yang dilakukan oleh orang- perseorangan ataupun korporasi/ badan hukum. PPATK dapat meminta bantuan aparat penegak hukum untuk me-lakukan penyelidikan, penyidikan, penuntutan dan sampai penuntasan kasus ini diha-dapan sidang pengadilan, untuk memberikan dan menjatuhkan hukuman terhadap pelakunya.

Terjalinnya kerja sama yang cukup sinergis antara aparat penegak hukum dengan PPATK, diharapkan dapat terbangun untuk menciptakan lembaga perbankan bersih dari segala bentuk dan modus kejahatan pencucian uang (money loundering). Sumber uang yang berasal dari segala bentuk kejahatan, korupsi, narkotika, perda-gangan manusia, perjudian dan lainnya. Tanpa dibangun kerjasama secara terpadu antara sesama aparat penegak hukum, aparat penegak hukum dengan Bank Indone-sia, Otoritas Jasa keuangan dan Pusat Pelaporan dan Analisis Transaksi keuangan, agak sukar untuk diungkap dan ditanggulangi tindak pidana di bidang perbankan tersebut.

Upaya penanggulangan tindak pidana di bidang perbankan, perlu ditopang dengan sarana dan prasarana yang ada pada aparat penegak hukum. Sarana dan atau fasilitas pendukung secara sederhana dapat dirumuskan sebagai sarana untuk menca-pai tujuan, yang mencakup di samping tersedianya tenaga manusia yang berpen-didikan dan trampil, organisasi yang mapan, dana operasional yang memadai, tentu yang lebih penting lagi tak dapat dipungkiri kebutuhan akan peralatan canggih yang cukup memadai.

Menghadapi era tehnologi mutakhir saat ini, berbagai modus tindak pidana per-bankan berkembang terus mengikuti trend global, transaksi bisnis yang dilakukan dengan nasabah selalu menggunakan tehnologi yang cukup canggih yang terkenal dengan istilah brandless banking, melalui fasilitas internet (e-banking), telepon seluler (m-banking), telepon (phone banking) ataupun pesan singkat (sms banking), sistem komputerisasi, penggunaan sistem online, penggunaan ATM, fasilitas kartu kredit dan lainnya. Kecepatan dan keandalan tehnologi mutakhir yang digunakan dalam industri perbankan, tidak boleh kalah cepatnya antisipasi aparat penegak hukum dalam melengkapi sarana dan fasilitas (peralatan 
tehnologi) yang mutakhir tersebut. Apabila sarana dan prasarana ini tidak mendapat perhatian aparat penegak hukum, mustahil kepastian dan kecepatan penegakan dan penerapan pidana dalam upaya penanggulangan tindak pidana perbankan akan dapat dicapai secara maksimal sebagaimana yang diharapkan.

Hambatan lain yang berpengaruh dalam penegakan dan penerapan pidana ter-hadap pelaku tindak pidana di bidang perbankan (tipibank) yang dihadapi aparat pe-negak hukum, yaitu apabila ada pelaku yang dengan sengaja melarikan diri ke luar negeri. Dengan melarikan diri ke luar negeri, tentu proses penegakan dan penerapan pidana dapat terhambat menjadi berlarut- larut walaupun sudah ditetapkan statusnya sebagai tersangka melakukan tindak pidana di bidang perbankan. Bukan persoalan terhadap tersangkanya saja yang tidak dapat diproses bahkan lebih dari itu, dapat menghambat pula proses penyitaan terhadap harta benda yang mereka miliki yang diperoleh dan/ atau bersumber dari hasil tindak pidana perbankan.

Persoalan tersangka yang dengan sengaja melarikan diri ke luar negeri, tentu menimbulkan persoalan tersendiri pula bagi aparat penegak hukum untuk mem-prosesnya, karena terbentuk dengan tidak adanya perjanjian ektradisi yang dibuat antara negara kita dengan tempat pelarian tersangka. Walaupun pernah dibuat dan diadakan serta ditanda tangani perjanjian ektradisi antara negara Indonesia dengan Singapura pada tanggal 27 April 2007 di Istana Tampaksiring Bali, dalam rangka memulangkan/mengembalikan pelaku tindak pidana perbankan yang menguras uang negara dalam kasus Bantuan Likuiditas Bank Indonesia (BLBI). ${ }^{41}$ Tetapi perjanjian ektradisi yang ditanda tangani kedua negara ini tidak ada kejelasan dan tindak lanjutnya. Hal ini dapat terjadi tidak epektif dan ditolaknya perjanjian ektradisi anta-ra Indonesia dengan Singapura, disebabkan dalam perjanjian tidak melahirkan keun-tungan yang bertimbal balik (amutual interest profit) bagi negara Singapura.

\section{Dilihat Dari aspek Budaya Hukum}

Kultur/budaya hukum yang merupakan sikap manusia (termasuk aparat penegak hukum) terhadap sistem dan penegakan hukum. Sebaik apapun penataan struktur hu-kum untuk menjalankan aturan hukum yang ditetapkan dan sebaik apapun kualitas substansi

\footnotetext{
${ }^{41}$ Jawahir Thontowi, Januari 2009, Perjanjian Ektradisi Indonesia Singapura, wordpress.com,Halaman 6.
} 
hukum yang dibuat, tanpa didukung oleh orang- orang yang terlibat (aparat penegak hukum) di dalam sistem hukum dan penegakan hukum, maka hukum tidak akan berjalan secara epektif.

Hukum yang dibuat pada akhirnya sangat ditentukan oleh budaya hukum yang berupa nilai, pandangan serta sikap dari masyarakat (termasuk aparat penegak hu-kum) yang bersangkutan. Jika budaya hukum itu diabaikan, maka akan dapat dipasti-kan terjadi kegagalan dari sistem hukum yang dibangun dan dipraktikan, yang ditan-dai dengan munculnya berbagai gejala, seperti ; kekeliruan informasi mengenai isi peraturan hukum yang ingin disampaikan kepada masyarakat, munculnya perbedaan antara apa yang dikehendaki oleh Undang- undang dengan praktik yang dijalankan oleh masyarakat. Masyarakat lebih memilih untuk tetap berprilaku sesuai apa yang telah menjadi nilai- nilai dan pandangan dalam kehidupan mereka. ${ }^{42}$

Tingkat kepercayaan masyarakat terhadap aparat penegak hukum dan praktik penegakan hukum yang buruk, harus diikuti dengan perbaikan struktur dan substansi hukum serta penerapan budaya hukumnya. Aspek budaya hukum memiliki peran yang cukup besar dalam penegakan hukum, mengingat budaya hukum merupakan si-kap manusia (termasuk aparat penegak hukum) terhadap sistem hukum dan penega-kan hukumnya.

Kepercayaan, nilai- nilai, pemikiran dan harapannya yang mencerminkan budaya hukum manusia merupakan suasana pikiran dan kekuatan sosial yang menentukan bagaimana hukum digunakan, dihindari dan atau disalahgunakan, tanpa adanya kultur/budaya hukum, maka sistem hukum itu sendiri tidak berdaya sebagaimana yang dikemukakan oleh Lawrence M. Friedman, 'without legal culture, the legal system is meetas dead fish lying in a basket, not a living fish swimming in its sea', ${ }^{43}$ yang menggambarkan budaya hukum merupakan bagian dari sistem hukum. Jika sistem hukum diibaratkan suatu pabrik, maka struktur diibaratkan merupakan mesin yang menghasilkan sesuatu, substansi diibaratkan sebagai produk yang dihasilkan oleh mesin dan budaya hukum merupakan apa saja atau siapa saja yang memutuskan un-tuk menjalankan mesin. Merekalah yang menentukan apa yang dihasilkan oleh me-sin, kapan mesin dihidupkan dan atau dimatikan, terlihat betapa besar peran budaya hukum dalam suatu sistem hukum itu sendiri untuk membangun dan menciptakan penegakan hukum yang memiliki dimensi

\footnotetext{
${ }^{42}$ Junaidi Maulana, Februari 2013, Budaya Hukum dan Penegakan Hukum, http ;//junaidimau-lana.blogspot,co.id, Halaman 6.

${ }^{43}$ Nita Ariyani, Agustus 2013, Peran Budaya Hukum Dalam Penegakan Hukum Pidana di Indo-nesia, lawandbeauty.blogspot.co.id,Halaman 8.
} 
keadilan, kemanfaatan dan kepastian hu-kum yang beroriensi kepada tercapainya kesejahtraan masyarakat.

Penting diperhatikan dalam upaya penanggulangan tindak pidana di bidang perbankan, perlu dibangun dan ditumbuh kembangkan budaya hukum adanya respon/ dukungan masyarakat. Untuk membangun dukungan masyarakat paling tidak aparat penegak hukum itu sendiri dapat memberikan budaya hukum yang baik dalam mene-gakan dan menerapkan pidana terhadap pelaku tindak pidana di bidang perbankan.

Budaya hukum yang terbentuk dari pemahaman, pemikiran, prilaku serta tin-dakan masyarakat terhadap hukum khususnya para aparat penegak hukum yang ter-kait dengan kebijakan dan aturan hukum. Budaya hukum inilah yang masih kurang diperhatikan dalam menelaah hambatan dalam proses tegaknya hukum tindak pidana di bidang perbankan. Bagian inilah yang sebenarnya perlu digali untuk mengetahui mengapa suatu aturan hukum yang sudah resmi diberlakukan tidak lancar dalam pelaksanaannya, apakah karena pemahaman hukum masyarakat yang kurang, apa-kah karena kesadaran hukum masyarakat yang belum memadai dan atau bahkan apa-kah karena aparat penegak hukum mempunyai pemikiran dan prilaku yang berbeda dengan hal yang sebenarnya yang terkandung dalam aturan yang diterapkan. ${ }^{44}$

Pengadilan yang merupakan representatif utama dari wajah penegakan hukum dituntut untuk tidak hanya mampu melahirkan kepastian hukum, melainkan pula keadilan, kemanfaatan dan pemberdayaan sosial melalui putusan- putusan hakimnya. Mengingat dengan adanya kegagalan lembaga peradilan dalam mewujudkan tujuan hukum di atas, telah mendorong meningkatnya ketidak percayaan masyarakat terha-dap pranata hukum dan lembaga- lembaga hukum. ${ }^{45}$

Salah satu masalah yang dihadapi bangsa ini adalah tidak adanya kepastian hu-kum. Belum terciptanya law enforcement (penegakan hukum) yang terpotret secara nyata dalam lembaga peradilan. Media massa bercerita banyak tentang hal ini, mulai dari mafia peradilan, suap ke hakim, pengacara tidak bermoral sampai kepada hukum yang berpihak pada kalangan tertentu, yang pada akhirnya perhatian masyarakat terhadap lembagalembaga hukum telah berada pada titik nadir. Salah satu perma-salahan yang perlu mendapat perhatian kita semua adalah merosotnya rasa hormat masyarakat terhadap

\footnotetext{
${ }^{44}$ Kusumaningtuti Sandriharmy, 2009, Peranan Hukum Dalam Penyelesaian Krisis Perbankan di Indonesia, PT. RajaGrafindo Persada : Jakarta, Halaman 25.

${ }^{45}$ Zudan Arif Fakrulloh, 2011, Ilmu Lembaga dan Pranata Hukum (Sebuah Pencarian), PT.RajaGrafindo Persada : Jakarta, Halaman 22.
} 
wibawa hukum. ${ }^{46}$ Hakim atau aparat penegak hukum seringkali bermain dengan peraturan dan prosedur. Hukum bukan dijalankan demi mencapai kesejahtraan dan keadilan, melainkan demi mencapai keadilan yang di-inginkan oleh aparat penegak hukum itu sendiri dan terdakwa di atas dalih hukum tertulis. ${ }^{47}$

Melihat kenyataan di atas, perlu ditumbuh kembangkan dengan baik budaya hukum aparat penegak hukum (kepolisian, kejaksaan, hakim pengadilan, lembaga pemasyarakatan dan advocat/pengacara) dalam penegakan hukum. Sebaik apapun peraturan perundangundang (Undang- undang Perbankan) yang dibuat, sedetil apapun kelembagaan dan manajemen organisasi aparat penegak hukum disusun, yang akan menjalankan adalah aparat penegak hukum yang ada dalam sistem dan budaya tersebut. Ketika budaya hukum yang dipraktikan belum berubah, aturan dan sistem tidak akan berjalan sesuai harapan.

Dalam rangka penegakan hukum tindak pidana di bidang perbankan harus di-lakukan 'pengorganisasian' secara terpadu, mengedepankan komitmen dan fakta in-tegritas, moral yang tinggi antar lembaga kepolisian, kejaksaan, hakim pengadilan, lembaga pemasyarakatan dan advocat/pengacara dengan menerapkan sistem hukum pidana dengan rencana tindakan nyata. Selain itu, perlu adanya dukungan dan komit-men kemauan politik (goodwill) yang kuat dari penguasa negara dengan suatu kebe-ranian moral dan konsistensi hukum dengan meresponnya.

Para aparat penegak hukum harus melepaskan diri dari budaya aparat penegak hukum yang ada selama ini tidak adil dan buruk dan berubah pola pikirnya ke arah peningkatan sumber daya manusia yang handal dan berkualitas. Budaya hukum dari aparat penegak hukum yang dipraktikan secara baik pada koridor hukum yang benar dan tidak memihak, tentu pada akhirnya akan dapat menciptakan dan menghasilkan penegakan hukum yang dapat memenuhi harapan masyarakat pencari keadilan.

\section{Kesimpulan}

Berdasarkan uraian pembahasan permasalahan di atas, maka dapat disimpulkan bahwa :

1. Kebijakan regulasi dalam upaya penanggulangan tindak pidana di bidang per-bankan diatur di dalam dan di luar Undang- undang Perbankan, yang di dalam Undang- undang

${ }^{46}$ Ibid, Halaman 23.

${ }^{47}$ Muhsin Hariyanto, 3 Februari 2012, Upaya Penegakan Hukum : Pembentukan Budaya Hukum Atas Dasar keadilan, muhsinhar.staff.umy.ac.id Halaman 7. 
Perbankan telah dirumuskan dan dituangkan ketentuannya di dalam pasal 46 hingga pasal 50A Undang- undang Perbankan Nomor 7 Tahun 1992 yang diperbaharui dengan Undang- undang Nomor 10 Tahun 1998, se-dangkan di luar ketentuan Undang- undang Perbankan, yang dituangkan dan diatur di dalam Kitab Undang- undang Hukum Pidana (KUHP), Undang- undang Pemberantasan Tindak Pidana Korupsi, Undang- undang Penanaman Modal, Undang- undang Pencegahan dan Pemberantasan Tindak Pidana Pencucian Uang, Undang- undang Informasi dan Transaksi Elektronik dan Undangundang Transper Dana.

2. Beberapa faktor yang merupakan penghambat dalam penanggulangan tindak pidana di bidang perbankan, dapat dilihat dari baik aspek substansi/materi yang termuat di dalam Undang- undang Perbankan, di mana norma/ kaidah hukumnya masih kabur, kurang jelas dan kurang tegas dan belum sepenuhnya mampu menanggulangi berbagai jenis dan modus tindak pidana di bidang perbankan yang terjadi dan berkembang saat ini. Dilihat dari aspek struktur/ kelembagaan aparat penegak hukum, masih terjadi tumpang tindih (overlaping) dan kurang harmonisnya antar aparat penegak hukum dalam hal kewenangan melakukan penyelidikan dan penyidikan tindak pidana di bidang perbankan yang diatur dalam Undang- undang. Keterbatasan kualitas (keahlian, ketrampilan, penga-laman dan pengetahuan) yang belum memadai penguasaan dan penggunaan tehnologi informasi, internet banking, data- data digital/ elektronik, komputeri-sasi dan lainnya, keterbatasan sarana dan prasarana tehnologi informasi maupun dari aspek kultur/budaya aparat penegak hukum yang berprilaku yang berbeda dengan hal yang sebenarnya yang terkandung dalam aturan yang diterapkan, seringkali bermain dengan peraturan dan prosedur. Hukum bukan dijalankan de-mi mencapai kesejahtraan dan keadilan, melainkan demi mencapai keadilan yang diinginkan oleh aparat penegak hukum itu sendiri dan terdakwa di atas dalih hukum tertulis.

\section{E. Rekomendasi}

Memperhatikan beberapa permasalahan yang ditemui dalam upaya penanggulangan tindak pidana di bidang perbankan melalui pendekatan kebijakan regulasi dan penerapan hukum pidana, maka rekomendasi diberikan penulis sebagai berikut ;

1. Perlu dilakukan reorientasi, rekonseptualisasi dan reformulasi dengan melakukan kebijakan kriminalisasi terhadap beberapa ketentuan yang belum diatur dan diru- 
muskan di dalam ketentuan Undang- undang perbankan Nomor 7 Tahun 1992 yang diperbaharui dengan Undang- undang Nomor 10 Tahun 1998.

2. Perlu dilakukan sinkronisasi dan harmonisasi aturan dalam Undang- undang pri-hal kewenangan penyelidikan dan penyidikan tindak pidana di bidang perbankan antara penyidik Otoritas Jasa keuangan (OJK) dengan penyidik lainnya,sehingga dapat dihindari terjadinya tumpah tindih (overlaping) kewenangan penyidikan antar aparat penegak hukum itu sendiri. Selain itu, perlu dilakukan peningkatan kualitas sumber daya manusia aparat penegak hukum dalam penguasaan tehno-logi informasi, prihal internet banking, kejahatan dunia maya, alat- alat bukti digital/elektronik, sarana dan prasarana tehnologi informasi yang cukup mema-dai, terutama penyediaan laboratorium criminal banking (kejahatan perbankan), peralatan komputerisasi dan lain sebagainya dalam mengantisipasi lajunya perkembangan tindak pidana perbankan dengan menggunakan tehnologi informasi yang cukup canggih.

\section{G. Daftar Pustaka}

Barda Nawawi Arief, Kapita Selekta Hukum Pidana, PT. Citra Aditya Bakti : Bandung, 2010.

Hermansyah, Hukum Perbankan Nasional Indonesia, Kencana : Jakarta, 2009.

H. Zainuddin Ali, Metode Penelitian Hukum, Sinar Grafika : Jakarta, 2009.

H.A.K. Moch. Anwar, Tindak Pidana di Bidang Perbankan, Alumni : Bandung, 1986.

Kasmir, Bank dan lembaga Keuangan Lainnya, PT. RajaGrafindo Persada : Jakarta, 2013.

Kusumaningtuti Sandriharmy, Peranan Hukum Dalam Penyelesaian Krisis Perbankan di Indonesia, PT. RajaGrafindo Persada : Jakarta, 2009.

Kristian dan Yopi Gunawan, Tindak Pidana Perbankan, Nuansa Aulia : Bandung, 2013,

Marwan Effendi, Tipologi Kejahatan Perbankan Dari Perspektif Hukum Pidana, CV. Sumber Ilmu Jaya : Jakarta, 2005,

Marulak Pardede, Hukum Pidana Bank, Pustaka Sinar Harapan : Jakarta, 1995,

Muhama Djumhana, Muhammad Djumhana, Hukum Perbankan di Indonesia, PT.Citra Aditya Bakti : Bandung, 2000.

Munir Fuady, Bisnis Kotor, Anatomi Kejahatan Kerah Putih, PT.Citra Aditya Bakti : Bandung, 2004.

Munir Fuady, Hukum Perbankan Modern Buku Kesatu, Pt. Citra Aditya Bakti : Bandung, 2003.

Muhammad Djumhana, Hukum Perbankan di Indonesia, PT.Citra Aditya Bakti : Bandung, 2000.

M. Arief Amrullah, Politik Hukum Pidana Dalam Perlindungan Korban, 2002.

Kejahatan Peter Mahmud Marzuki, Penelitian Hukum, Kencana : Jakarta, 2006.

M. Sholehuddin, Sistem Sanksi Dalam Hukum Pidana : Ide Dasar Doble Track Sistem dan Implementasinya, PT. RajaGrafindo Persada : Jakarta, 2003. 
Rachmadi Usman, Aspek- aspek Hukum Perbankan di Indonesia, PT.Gramedia Pustaka Utama : Jakarta, 2001.

Sutan Remy Sjahdeini, Pertanggungjawaban Pidana Korporasi, Grafiti Pers : Jakarta, 2006.

Supanto, Kejahatan Ekonomi Global dan Kebijakan Hukum Pidana, Alumni : Bandung, 2010.

Widjanarto, Hukum dan Ketentuan Perbankan di Indonesia, Grafiti : Jakarta, 2005,

Yunus Husein, Rahasia Bank dan Penegakan Hukum, Pustaka Juanda Tiga Lima : Jakarta, 2010.

Yusuf Shofie, Perlindungan Konsumen dan Instrument- instrument Hukumnya, PT. Citra Aditya Bakti : Bandung, 2009.

Yunan Sawidji, Kebijakan Penal Indonesia Terhadap Kejahatan Teroganisir, Fak. Hukum UGM : Jogyakarta, 1996.

Zulkarnaen Sitompul, Problematika Perbankan, Books Terrrance \& Library : Bandung, 2005 ,

Zudan Arif Fakrulloh, Ilmu Lembaga dan Pranata Hukum (Sebuah Pencarian), PT.RajaGrafindo Persada : Jakarta, 2011, 